Document downloaded from:

http://hdl.handle.net/10251/51768

This paper must be cited as:

Berenguer Betrián, R.; Sieben, JM.; Quijada Tomás, C.; Morallón, E. (2014). Pt- and Rudoped $\mathrm{SnO} 2-\mathrm{Sb}$ anodes with high stability in alkaline medium. ACS Applied Materials and Interfaces. (6):22778-22789. doi:10.1021/am506958k.

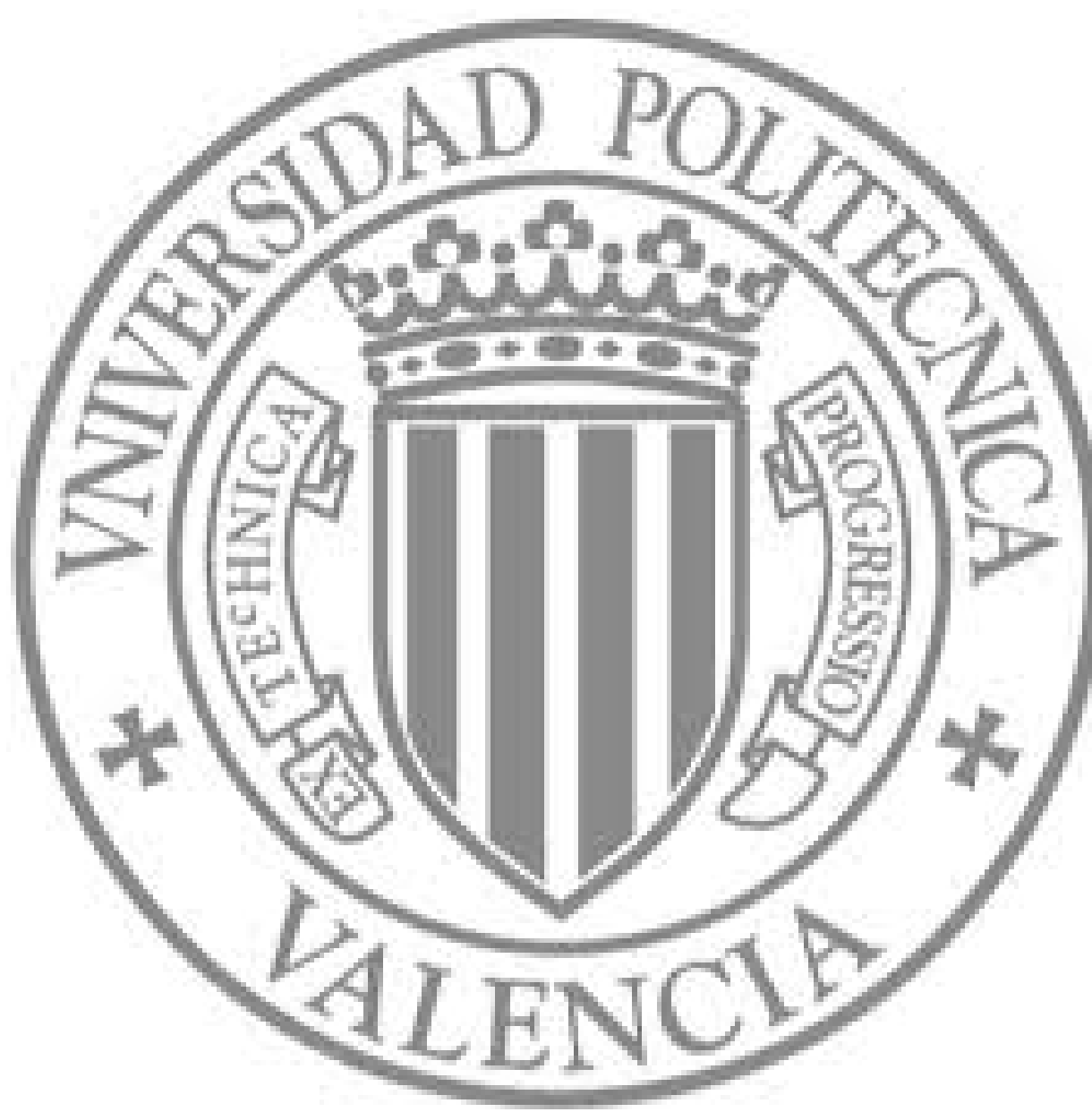

The final publication is available at

http://pubs.acs.org/doi/abs/10.1021/am506958k

Copyright American Chemical Society 
Subscriber access provided by UNIVERSITAT POLITÈCNICA DE VALÈNCIA

\title{
Article
}

\section{Pt- and Ru-doped SnO2-Sb anodes with high stability in alkaline medium}

\author{
Raúl Berenguer, Juan Manuel Sieben, Cesar Quijada, and Emilia Morallon
}

ACS Appl. Mater. Interfaces, Just Accepted Manuscript • DOI: 10.1021/am506958k • Publication Date (Web): 02 Dec 2014

Downloaded from http://pubs.acs.org on December 3, 2014

\section{Just Accepted}

"Just Accepted" manuscripts have been peer-reviewed and accepted for publication. They are posted online prior to technical editing, formatting for publication and author proofing. The American Chemical Society provides "Just Accepted" as a free service to the research community to expedite the dissemination of scientific material as soon as possible after acceptance. "Just Accepted" manuscripts appear in full in PDF format accompanied by an HTML abstract. "Just Accepted" manuscripts have been fully peer reviewed, but should not be considered the official version of record. They are accessible to all readers and citable by the Digital Object Identifier (DOI®). "Just Accepted" is an optional service offered to authors. Therefore, the "Just Accepted" Web site may not include all articles that will be published in the journal. After a manuscript is technically edited and formatted, it will be removed from the "Just Accepted" Web site and published as an ASAP article. Note that technical editing may introduce minor changes to the manuscript text and/or graphics which could affect content, and all legal disclaimers and ethical guidelines that apply to the journal pertain. ACS cannot be held responsible for errors or consequences arising from the use of information contained in these "Just Accepted" manuscripts.

\section{ACS Publications}




\title{
Pt- and $\mathrm{Ru}$-doped $\mathrm{SnO}_{2}$-Sb anodes with high
}

\section{stability in alkaline medium}

\author{
Raúl Berenguer $^{a}$, Juan Manuel Sieben ${ }^{b}$, César Quijada ${ }^{c}$, Emilia Morallón $^{d, *}$ \\ a Universidad de Málaga, Andalucía Tech, Departamento de Ingeniería Química, 29071 Málaga, \\ Spain. \\ ${ }^{\mathrm{b}}$ Instituto de Ingeniería Electroquímica y Corrosión and CONICET, Universidad Nacional del \\ Sur, Av. Alem 1253, (B8000CPB) Bahía Blanca, Argentina. \\ ${ }^{\mathrm{c}}$ Departamento de Ingeniería Textil y Papelera, Universidad Politécnica de Valencia, Plaza de \\ Ferrándiz y Carbonell, E-03801 Alcoy (Alicante), Spain.

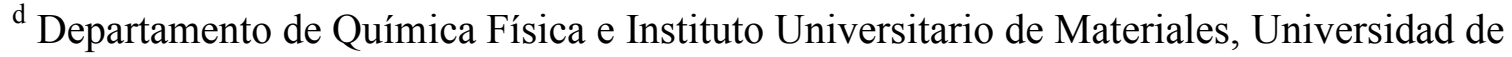 \\ Alicante, Apartado 99, E-03080 Alicante, Spain.
}




\begin{abstract}
Different Pt- and $\mathrm{Ru}$-doped $\mathrm{Ti} / \mathrm{SnO}_{2}-\mathrm{Sb}$ electrodes were synthesized by thermal decomposition. The effect of the gradual substitution of $\mathrm{Sb}$ by $\mathrm{Ru}$ in the nominal composition on the physicochemical and electrochemical properties were evaluated. The electrochemical stability of the electrodes was estimated from accelerated tests at $0.5 \mathrm{~A} \mathrm{~g}^{-1}$ in $1 \mathrm{M} \mathrm{NaOH}$. Both assynthesized and deactivated electrodes were thoroughly characterized by scanning electron microscopy (SEM), energy-dispersive X-ray microanalysis (EDX), transmission electron microscopy (TEM), X-Ray photoelectron spectroscopy (XPS) and X-Ray diffraction analysis (XRD). The incorporation of a small amount (about 3 at.\%) of both $\mathrm{Pt}$ and $\mathrm{Ru}$ into the $\mathrm{SnO}_{2}-\mathrm{Sb}$ electrodes produced a 400-times increase in their service life in alkaline medium, with no remarkable change in the electrocatalysis of the Oxygen Evolution Reaction (OER). It is concluded that the deactivation of the electrodes is promoted by alkaline dissolution of metal species and coating detachment at high potentials. The introduction of $\mathrm{Pt}$ has a coating compacting effect, and $\mathrm{Ru}(\mathrm{IV})$, at low amounts until 9.75 at.\%, replaces the $\mathrm{Sn}(\mathrm{IV})$ cations in the rutile-like $\mathrm{SnO}_{2}$ structure to form a solid solution that strongly increases the stability of the electrodes. The observed Ru segregation and decreased stability for larger Ru contents ( $\mathrm{x}>9.75$ at. \%), together with the selective dissolution of $\mathrm{Ru}$ after deactivation, suggest that the formation of a homogeneous $\left(\mathrm{Ru}_{\delta} \mathrm{Sn}_{1-\delta}\right) \mathrm{O}_{2}$ single-phase is crucial for the stabilization of these electrodes.
\end{abstract}

\begin{abstract}
Keywords: DSA electrodes, doped tin dioxide electrodes, electrochemical stability, ruthenium oxide, alkaline solutions.
\end{abstract}




\section{Introduction}

Due to their unique properties and extremely high versatility, transition metal oxides (TMOs) have received a great interest as electrodes in many electrochemical applications. ${ }^{1-17}$ Thus, they have been widely used in the chlor-alkali industry, ${ }^{2}$ and multiple processes using electrolyzers, ${ }^{2-4}$ and constitute promising electrode materials for more sustainable and environmentally-friendly technologies in water remediation ${ }^{5-12}$ and energy storage and conversion. ${ }^{13-16}$ Apart from a suitable performance, the economics and feasibility of the TMOs electrodes in these applications largely depend on their service life at operation conditions. ${ }^{1,17}$

The tremendous success of some active TMOs $\left(\mathrm{RuO}_{2}, \mathrm{IrO}_{2}, \mathrm{Co}_{3} \mathrm{O}_{4}\right.$, etc.) supported onto a $\mathrm{Ti}$ substrate (the so-called dimensionally stable anodes, DSA), can be associated to their high stability and long lifetime at high potentials in aqueous electrolytes, where the oxygen evolution reaction (OER) occurs, as well as their good catalytic activity for this reaction, what provide lower cell-voltages and better faradic efficiencies in multiple processes. ${ }^{1,2,17}$ Nevertheless, for some applications, such as the electrochemical degradation of pollutants in wastewater, ${ }^{5-12}$ the electrodes should have not only a good stability but also a high overpotential for the OER sidereaction.

The composition and the nature of the oxide coating strongly affect the stability and electrochemical activity of these DSA electrodes. ${ }^{1,17-19}$ Due to their high OER overpotential, considerably lower cost and innocuous character, the $\mathrm{Sb}$-doped $\mathrm{SnO}_{2}$ electrodes ${ }^{20-22}$ have been found to be, among different choices, the most promising alternatives to the more expensive and fragile Boron-Doped Diamond (BDD) electrodes, ${ }^{12,23,24}$ and the more harmful, lead-leaching, $\mathrm{PbO}_{2}$-based electrodes. ${ }^{25}$ Unfortunately, their anodic stability is remarkably low. ${ }^{20,21,26,27}$ 
Although different approaches have been proposed to increase the stability of the $\mathrm{SnO}_{2}$-based electrodes, most of them focused on acid electrolytes, ${ }^{21,28,29,30}$ while the stability enhancement in alkaline medium has received less attention. ${ }^{31}$ In general, the combination of $\mathrm{SnO}_{2}$-based electrodes with active species ( $\mathrm{Pt}, \mathrm{Ir}, \mathrm{Ru})$ enhances their stability, but it simultaneously increases the catalytic activity towards the OER and the cost of the electrodes; however, the optimization of the amount of active metal has not been often considered. ${ }^{5-12}$ In addition, these investigations mainly determined the service life of the electrodes without deepening into a detailed characterization of fresh and deactivated electrodes. So the understanding of the stabilization effect and the deactivation mechanisms need further research.

Considering the growing application of electrochemistry in different fields, the development of high-performance electrodes for alkaline electrolytes gathering both high OER-overpotential and stability, is very interesting for multiple electrochemical applications, such as fuel cells, electrooxidation of compounds in electrosynthesis or the electrochemical degradation of pollutants, etc. ${ }^{1-17}$ For this purpose, the establishment of structure-composition vs. stability correlations and the investigation of the deactivation mechanism of the electrodes are of utmost importance to further propose new stabilization strategies.

It has been previously found that the introduction of a small amount ( 3 at. \%) of Pt enhances the service life of Sb-doped $\mathrm{SnO}_{2}$ electrodes in acidic electrolyte by two orders of magnitude, ${ }^{28}$ also showing an even higher efficiency for phenol electro-oxidation in the same medium; however, higher amounts of $\mathrm{Pt}\left(13\right.$ at. \%) decrease their performance. ${ }^{32}$ On the other hand, it is well documented that $\mathrm{RuO}_{2}$ exhibits a high catalytic activity and stability for the OER. ${ }^{31,33}$ The stability of binary $(\mathrm{Sn}-\mathrm{Ru}) \mathrm{O}_{2}$ oxides were previously studied, but experiments were restricted to acidic medium $^{29,34}$ and the influence of $\mathrm{Sb}$ or Pt was not considered. Consequently, in this work 
we have investigated the influence of $\mathrm{Pt}$, as well as the progressive substitution of $\mathrm{Sb}$ by $\mathrm{Ru}$ in the nominal composition of $\mathrm{SnO}_{2}-\mathrm{Sb} / \mathrm{Ti}$ electrodes, on the physicochemical properties and the electrochemical response of the electrode. For this purpose, different $\mathrm{SnO}_{2}-\mathrm{Sb}(13-\mathrm{x})-\mathrm{Pt}(3)$ $\operatorname{Ru}(\mathrm{x}) / \mathrm{Ti}$ electrodes $(0 \leq \mathrm{x}($ at. $\%) \leq 13)$, were synthesized by thermal decomposition and thoroughly characterized, before and after deactivation. The electrochemical stability of the electrodes was estimated by accelerated tests at $0.5 \mathrm{~A} \mathrm{~g}^{-1}$ in $1 \mathrm{M} \mathrm{NaOH}$. The structural properties were studied by SEM, TEM and XRD, whereas the chemical composition was followed by EDX and XPS. The electrochemical behavior as well as the catalytic activity towards the OER was analyzed by cyclic voltammetry and Tafel measurements, respectively, in the same electrolyte. Furthermore, $\mathrm{SnO}_{2}-\mathrm{Sb} / \mathrm{Ti}, \mathrm{SnO}_{2}-\mathrm{Ru} / \mathrm{Ti}$ and $\mathrm{RuO}_{2} / \mathrm{Ti}$ electrodes were prepared and characterized by the same techniques.

\section{Experimental}

Four types of tetragonal rutile-like oxide electrodes (with composition in brackets expressed as metal atomic percentage), $\mathrm{SnO}_{2}-\mathrm{Sb}(13$ at. $\%), \mathrm{SnO}_{2}-\mathrm{Sb}(13-\mathrm{x})-\mathrm{Pt}(3)-\mathrm{Ru}(\mathrm{x})$ (with $0 \leq \mathrm{x} \leq 13$ at. $\%), \mathrm{SnO}_{2}-\mathrm{Ru}\left(13\right.$ at. \%) and $\mathrm{RuO}_{2}$, were synthesized by the thermal decomposition method following the procedure described elsewhere. ${ }^{33}$ Briefly, the precursor solutions, consisting of $\mathrm{SnCl}_{4} \cdot 5 \mathrm{H}_{2} \mathrm{O}, \mathrm{SbCl}_{3}, \mathrm{H}_{2} \mathrm{PtCl}_{6} \cdot 6 \mathrm{H}_{2} \mathrm{O}$ and $\mathrm{RuCl}_{3} \cdot \mathrm{nH}_{2} \mathrm{O}$ in absolute ethanol and $\mathrm{HCl}$ with the desired nominal composition, were spread over pre-treated Ti plates $(1 \mathrm{~cm} \times 1 \mathrm{~cm} \times 0.05 \mathrm{~cm}$; Goodfellow $99.6 \%$ ) by brushing. Previously, the Ti plates were degrased in acetone, etched in a boiling $10 \%$ oxalic acid solution for $1 \mathrm{~h}$ and finally rinsed with distilled water. The sample was dried at $70{ }^{\circ} \mathrm{C}$ in order to evaporate the solvent and the metal oxides were formed by calcination at $400{ }^{\circ} \mathrm{C}$ for $10 \mathrm{~min}$. This procedure was successively repeated to increase the oxide loading up 
to ca. $1.5-2.0 \mathrm{mg} \mathrm{cm}^{-2}$. The number of deposition steps for these loadings were between 20 and 25. A final annealing step was carried out for $60 \mathrm{~min}$ at $600^{\circ} \mathrm{C}$.

The nominal composition of the precursor solution is presented in Table 1 . In all cases, the total metal cation concentration was kept constant at $0.5 \mathrm{~m}$.

Table 1. Nominal composition of the precursor solutions for the different electrodes.

\begin{tabular}{|c|c|c|c|c|c|c|}
\hline & & \multicolumn{4}{|c|}{ (g) salt precursor/100 (g) solution } & \multirow[b]{2}{*}{$\begin{array}{c}\text { Ethanol } \\
\text { (ml) }\end{array}$} \\
\hline Electrode & $(\mathrm{x})^{\mathrm{a}}$ & $\begin{array}{r}\mathrm{SnCl}_{4} \\
\cdot 5 \mathrm{H}_{2} \mathrm{O}\end{array}$ & $\mathrm{SbCl}_{3}$ & $\begin{array}{r}\mathrm{H}_{2} \mathrm{PtCl}_{6} \\
\cdot 6 \mathrm{H}_{2} \mathrm{O}\end{array}$ & $\begin{array}{l}\mathrm{RuCl}_{3} \\
\cdot \mathrm{nH}_{2} \mathrm{O}\end{array}$ & \\
\hline $\mathrm{SnO}_{2}-\mathrm{Sb} / \mathrm{Ti}$ & 0.00 & 10.000 & 1.000 & --- & --- & 112.7 \\
\hline \multirow{5}{*}{$\begin{array}{c}\mathrm{SnO}_{2}-\mathrm{Sb}(13-\mathrm{x})- \\
\mathrm{Ru}(\mathrm{x})-\mathrm{Pt} / \mathrm{Ti}\end{array}$} & 0.00 & 10.000 & 1.000 & 0.400 & --- & 112.4 \\
\hline & 3.25 & 10.000 & 0.750 & 0.400 & 0.287 & 112.4 \\
\hline & 6.50 & 10.000 & 0.500 & 0.400 & 0.573 & 112.3 \\
\hline & 9.75 & 10.000 & 0.250 & 0.400 & 0.860 & 112.3 \\
\hline & 13.00 & 10.000 & --- & 0.400 & 1.146 & 112.2 \\
\hline $\mathrm{SnO}_{2}-\mathrm{Ru} / \mathrm{Ti}$ & 13.00 & 10.000 & -- & -- & 1.146 & 112.5 \\
\hline $\mathrm{Ti} / \mathrm{RuO}_{2} / \mathrm{Ti}$ & 100 & --- & --- & --- & 5.186 & 50.0 \\
\hline
\end{tabular}

a (x): nominal $\mathrm{Ru}$ percentage

\subsection{Physicochemical characterization}

The surface morphology of the electrodes was studied by scanning electron microscopy (SEM) in a Hitachi S-3000N electron microscope coupled to a Rontec X-ray detector for energy dispersive X-ray (EDX) microanalysis. The microstructure and crystallinity were characterized by X-ray diffraction (XRD) in a KRISTALLOFLEX K 760-80F diffractometer (Bruker D8- 
Advance) by using a Ni-filtered $\mathrm{Cu} K \alpha$ radiation $(\lambda=1.5416 \AA)$. Diffraction data points were recorded stepwise within $2 \theta=20-80^{\circ}$ at a scan rate of $0.03^{\circ} \mathrm{min}^{-1}$ with a scan step of $0.05^{\circ}$ in 20. Cell parameters were calculated by a computer program using the peak position obtained after fitting the experimental range with a pseudo-Voigt function per peak plus a background line. Line-broadening analysis was performed to determine the average crystallite size.

The morphology and particle size were analyzed by transmission electron microscope (TEM) in a JEOL equipment (JEM-2010) with an accelerating voltage of $200 \mathrm{keV}$. X-ray photoelectron spectroscopy (XPS) measurements were carried out by a VG-Microtech Multilab 3000 spectrometer with $\mathrm{Mg} \mathrm{K} \alpha$ radiation $(\mathrm{hv}=1256.3 \mathrm{eV})$ at base pressure of $5 \times 10^{-10}$ mbar in the analysis chamber. Binding energies were referenced against the main $C(1 \mathrm{~s})$ line of adventitious carbon impurities at $284.6 \mathrm{eV}$. Peak energies were given to an accuracy of $0.2 \mathrm{eV}$ and peak areas were normalized by using appropriate atomic sensitivity factors.

\subsection{Electrochemical measurements}

The electrochemical measurements were performed on an Autolab PGSTAT 30 potentiostat controlled by GPES EcoChimie software using a conventional three-electrode glass cell. The counter electrode was a spiral of platinum wire of $12 \mathrm{~cm}$ length and $0.5 \mathrm{~mm}$ of diameter and the potentials are referred to a reversible hydrogen electrode (RHE) immersed in the same solution. The aqueous $0.1 \mathrm{M} \mathrm{NaOH}$ solutions were de-oxygenated by $\mathrm{N}_{2}$ bubbling. All solutions were prepared with purified water obtained from an Elga Labwater Purelab system $(18.2 \mathrm{M} \Omega \mathrm{cm})$. In these studies, cyclic voltammetry (CV) measurements were performed between different potential limits at a scan rate between 1 and $500 \mathrm{mV} \mathrm{s}^{-1}$. The current densities were calculated using the apparent geometric area of the electrodes $\left(2 \mathrm{~cm}^{2}\right)$. The voltammetric charges $\left(\mathrm{q}^{*}\right)$ 
corresponding to electrochemically active surface areas were determined by integrating the area of the cyclic voltammograms. The electrocatalytic activity towards OER was investigated in aqueous $0.1 \mathrm{M} \mathrm{NaOH}$ solution by galvanostatic experiments at current densities lower than $5 \mathrm{~mA}$ $\mathrm{cm}^{-2}$ at a scan rate of $3 \mu \mathrm{A} \mathrm{s}{ }^{-1}$.

The accelerated service-life tests were performed by anodic polarization of the different electrodes at $0.5 \mathrm{~A} \mathrm{~cm}^{-2}$ in a $1 \mathrm{M} \mathrm{NaOH}$ solution at a controlled temperature of $25^{\circ} \mathrm{C}$. The anode potential was measured as a function of time, and the electrode was considered to be deactivated when the potential increased to $5 \mathrm{~V}$ above its initial value. In these experiments a $\mathrm{Ag} / \mathrm{AgCl} / \mathrm{Cl}^{-}$ (sat.) electrode served as the reference electrode. The electrolyte composition after the anodic deactivation treatment was determined by ICP-OES analysis (Perkin Elmer 7300 DV).

\section{Results and discussion}

3.1. Physicochemical characterization.

3.1.1. Surface morphology.

The as-prepared $\mathrm{SnO}_{2}-\mathrm{Sb} / \mathrm{Ti}, \mathrm{RuO}_{2} / \mathrm{Ti}$ and $\mathrm{SnO}_{2}-\mathrm{Sb}-\mathrm{Pt} / \mathrm{Ti}$ electrodes (Fig. 1a,c,e, respectively) exhibit the typical cracked-mud morphology of these metal oxide coatings prepared by thermal decomposition..$^{20,21,28,35}$ These surface cracks may be produced during the electrode cooling to room temperature ${ }^{20,28}$ and/or by solvent evaporation during heating stages. ${ }^{36}$ Nevertheless, the incorporation of a small amount of $\mathrm{Pt}\left(3\right.$ at. \%) in the $\mathrm{SnO}_{2}-\mathrm{Sb}$ layer (Fig. 1e) significantly reduces the number of cracks and pores, producing a compacting effect that has been attributed to a strengthening and shortening of the oxide intercolumn bondings caused by Pt aggregates on the surface of $\mathrm{SnO}_{2}$ grains. ${ }^{37}$ 

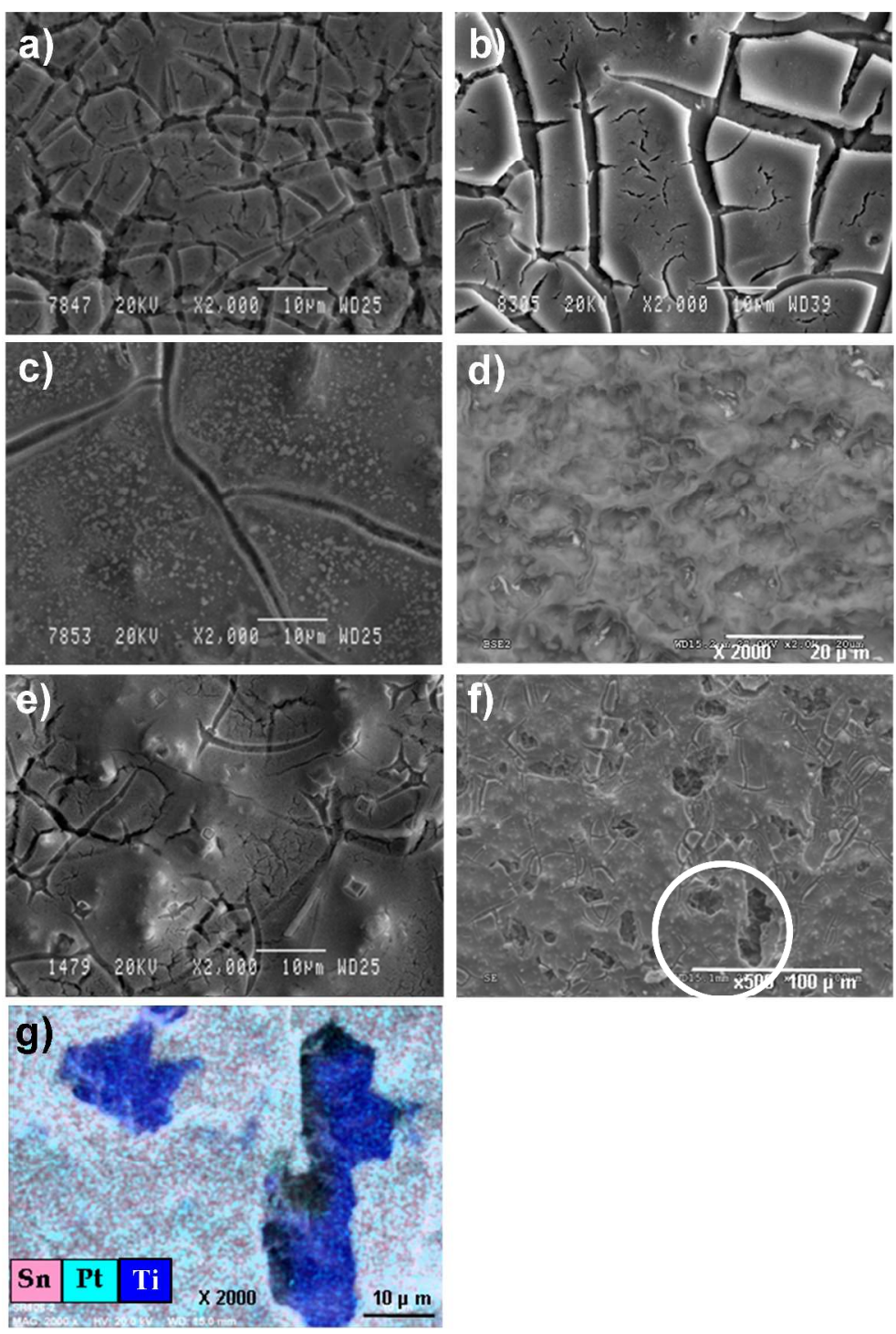

Figure 1. SEM images of (a) fresh $\mathrm{SnO}_{2}-\mathrm{Sb} / \mathrm{Ti}$ electrode, (b) deactivated $\mathrm{SnO}_{2}-\mathrm{Sb} / \mathrm{Ti}$ electrode, (c) fresh $\mathrm{RuO}_{2} / \mathrm{Ti}$ electrode, (d) deactivated $\mathrm{RuO}_{2} / \mathrm{Ti}$ electrode, (e) fresh $\mathrm{SnO}_{2}-\mathrm{Sb}-\mathrm{Pt} / \mathrm{Ti}$ electrode, (f) deactivated $\mathrm{SnO}_{2}-\mathrm{Sb}-\mathrm{Pt} / \mathrm{Ti}$ electrode and (g) EDX-mapping of the circled area in (f)

The surface cracks on the $\mathrm{SnO}_{2}-\mathrm{Sb}-\mathrm{Pt} / \mathrm{Ti}$ oxide layer disappear and porosity dramatically increases upon substituting $\mathrm{Sb}$ with 3.25 at. \% $\mathrm{Ru}$ in the nominal composition (Fig. 2a). However, further incorporation of $\mathrm{Ru}(6.50-9.75$ at. \%) gradually reduces the oxide surface 
roughness (Fig. 2b-c) until the cracked-mud structure is restored again at a ruthenium content of 13 at. $\%$ (Fig. 2 d). ${ }^{33}$ In addition, the presence of small grains is also observed in these latter electrodes (Fig. 2d). The EDX mapping shows that the small grains contain a high concentration of $\mathrm{Ru}$, indicating phase separation. The phase separation/segregation of $\mathrm{Ru}$ in $\mathrm{Sn}-\mathrm{Ru}$ mixed oxides synthesized by traditional methods has been reported in the literature. ${ }^{38-40}$
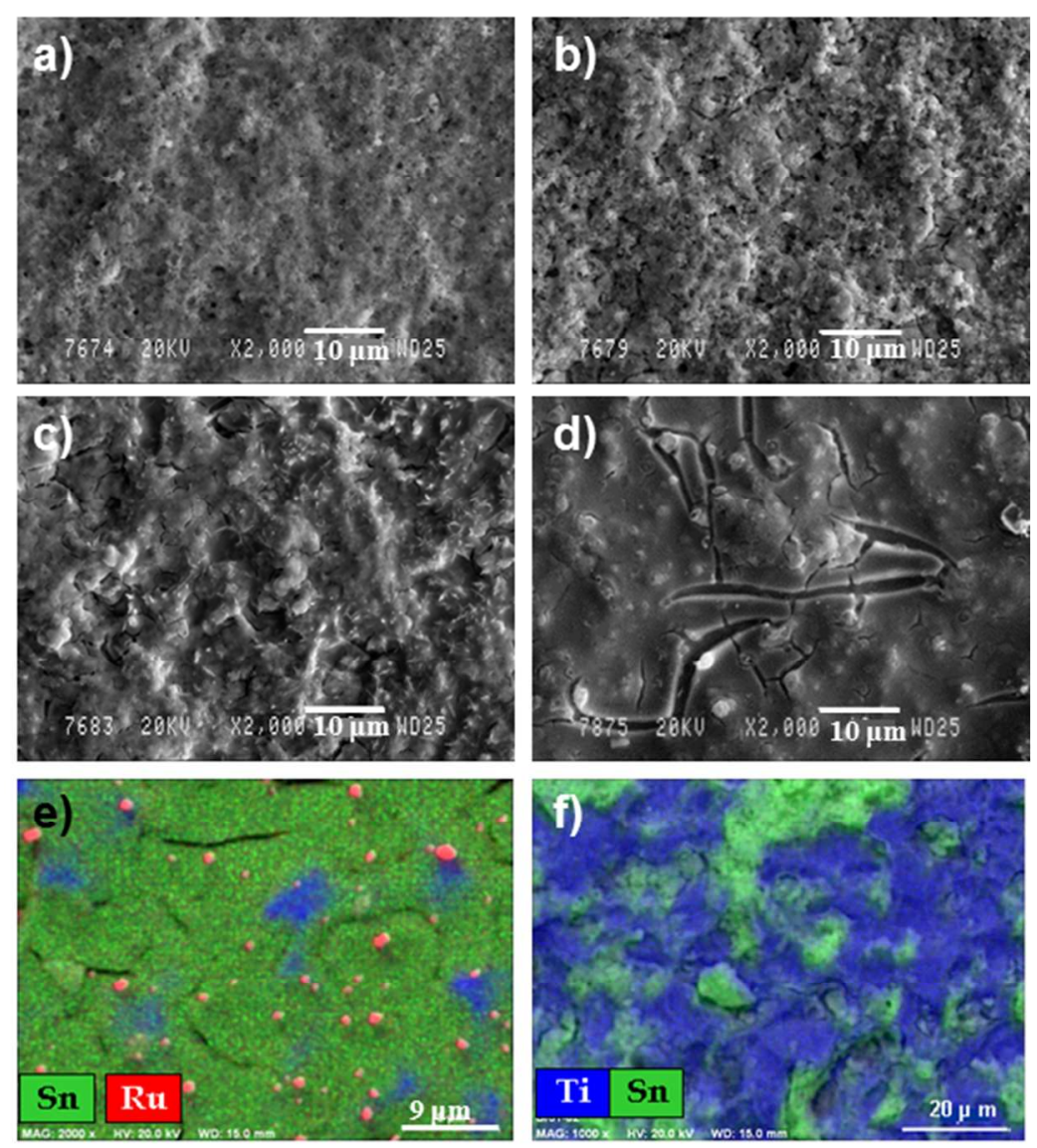

Figure 2. $\mathrm{SEM}$ images of fresh $\mathrm{SnO}_{2}-\mathrm{Sb}(13-\mathrm{x})-\mathrm{Pt}-\mathrm{Ru}(\mathrm{x}) / \mathrm{Ti}$ electrodes with $\mathrm{x}=3.25$ at. \% $(\mathrm{Ru})$ (a), $x=6.50$ at. $\%(\mathrm{Ru})(\mathrm{b}), \mathrm{x}=9.75$ at. $\%(\mathrm{Ru})(\mathrm{c}), \mathrm{x}=13.00$ at. $\%(\mathrm{Ru})(\mathrm{d})$, fresh $\mathrm{SnO}_{2}-\mathrm{Ru} / \mathrm{Ti}$ electrode (e); and deactivated $\mathrm{SnO}_{2}-\mathrm{Sb}(13-\mathrm{x})-\mathrm{Pt}-\mathrm{Ru}(\mathrm{x}) / \mathrm{Ti}$ electrode; $\mathrm{x}=3.25$ at.\% $\mathrm{Ru}$ (f).

\subsubsection{Chemical composition.}


EDX spectra and mappings registered at different regions of the electrode surfaces showed a homogeneous distribution of the elements in the oxide films. The low signals from the underlying $\mathrm{Ti}$ evidenced that a good coverage of the substrate was achieved. According to the methodology reported elsewhere, ${ }^{28,33}$ the coating thickness estimated from oxide loadings ranged between 2 and $3 \mu \mathrm{m}$. The nominal and experimental compositions of the different mixed metal oxides were expressed as the amount of individual metals with respect to the total metal content, M, (atomic ratios) (Table 2). Comparisons between bulk and surface compositions, obtained by EDX and XPS analysis, respectively, provided some insight into the distribution of the different species. The fairly good correlation between the nominal and EDX experimental Sn/M and Sb/M ratios in $\mathrm{SnO}_{2}-\mathrm{Sb} / \mathrm{Ti}$ and $\mathrm{SnO}_{2}-\mathrm{Sb}-\mathrm{Pt} / \mathrm{Ti}(\mathrm{x}=0.00 \%)$ electrodes points out that $\mathrm{Sn}$ and $\mathrm{Sb}$ were successfully combined in the desired proportions, although $\mathrm{Sb}$ depletion occurs at the surface of these electrodes. 
Table 2. Nominal and experimental EDX and XPS atomic ratios with respect to the total metal content (M) obtained for (fresh) and deactivated (deact.) electrodes.

\begin{tabular}{|c|c|c|c|c|c|c|c|c|c|c|c|c|c|c|c|c|c|c|c|}
\hline \multirow{3}{*}{$\begin{array}{l}\text { Electrode } \\
\mathrm{SnO}_{2}-\mathrm{Sb} / \mathrm{Ti}\end{array}$} & \multirow{3}{*}{\begin{tabular}{c|}
$(\mathrm{x})$ \\
-
\end{tabular}} & \multicolumn{4}{|c|}{$\mathrm{Sn} / \mathrm{M}^{\mathrm{a}}$} & \multicolumn{4}{|c|}{$\mathrm{Sb} / \mathrm{M}$} & \multicolumn{4}{|c|}{$\mathrm{Pt} / \mathrm{M}$} & \multicolumn{4}{|c|}{$\mathrm{Ru} / \mathrm{M}$} & \multicolumn{2}{|c|}{$\mathrm{I}_{\mathrm{OH}} / \mathrm{I}_{\mathrm{OM}}{ }^{\mathrm{b}}$} \\
\hline & & Nom. & $\begin{array}{l}\text { EDX } \\
\text { fresh }\end{array}$ & $\begin{array}{l}\text { XPS } \\
\text { fresh }\end{array}$ & $\begin{array}{l}\text { XPS } \\
\text { deact }\end{array}$ & Nom. & $\begin{array}{l}\text { EDX } \\
\text { fresh }\end{array}$ & $\begin{array}{l}\text { XPS } \\
\text { fresh }\end{array}$ & $\begin{array}{l}\text { XPS } \\
\text { deact }\end{array}$ & Nom. & $\begin{array}{l}\text { EDX } \\
\text { fresh }\end{array}$ & $\begin{array}{l}\text { XPS } \\
\text { fresh }\end{array}$ & $\begin{array}{l}\text { XPS } \\
\text { deact }\end{array}$ & Nom. & $\begin{array}{l}\text { EDX } \\
\text { fresh }\end{array}$ & $\begin{array}{l}\text { XPS } \\
\text { fresh }\end{array}$ & $\begin{array}{l}\text { XPS } \\
\text { deact }\end{array}$ & $\begin{array}{l}\text { XPS } \\
\text { fresh }\end{array}$ & $\begin{array}{l}\text { XPS } \\
\text { deact }\end{array}$ \\
\hline & & 0.87 & 0.88 & 0.94 & 0.92 & 0.13 & 0.12 & 0.06 & 0.07 & - & - & - & - & - & - & - & - & 0.27 & 0.12 \\
\hline & 0.00 & 0.84 & 0.83 & 0.88 & 0.90 & 0.13 & 0.11 & 0.07 & 0.05 & 0.03 & 0.06 & 0.04 & 0.06 & - & - & - & - & 0.24 & 0.18 \\
\hline $\mathrm{SnO}_{2-}$ & 3.25 & 0.84 & 0.69 & 0.66 & 0.73 & 0.10 & 0.24 & 0.32 & 0.10 & 0.03 & 0.04 & 0.02 & 0.17 & 0.03 & 0.03 & 0.00 & 0.00 & 0.54 & 0.34 \\
\hline $\mathrm{Sb}(13-\mathrm{x})-$ & 6.50 & 0.84 & 0.69 & 0.71 & 0.79 & 0.06 & 0.19 & 0.21 & 0.07 & 0.03 & 0.05 & 0.06 & 0.14 & 0.06 & 0.07 & 0.02 & 0.00 & 0.32 & 0.27 \\
\hline \multirow[t]{2}{*}{$\operatorname{Pt}-\mathrm{Ru}(\mathrm{x}) / \mathrm{Ti}$} & 9.75 & 0.84 & 0.72 & 0.90 & 0.85 & 0.03 & 0.10 & 0.05 & 0.09 & 0.03 & 0.06 & 0.03 & 0.06 & 0.10 & 0.12 & 0.02 & 0.00 & 0.23 & 0.12 \\
\hline & 13.00 & 0.84 & 0.78 & 0.96 & 0.87 & - & - & - & - & 0.03 & 0.06 & 0.02 & 0.11 & 0.13 & 0.16 & 0.02 & 0.02 & 0.27 & 0.30 \\
\hline $\mathrm{SnO}_{2}-\mathrm{Ru} / \mathrm{Ti}$ & - & 0.87 & 0.79 & 0.96 & 0.98 & - & - & - & - & - & - & - & - & 0.13 & 0.21 & 0.04 & 0.02 & 0.55 & 0.26 \\
\hline $\mathrm{RuO}_{2} / \mathrm{Ti}$ & - & - & - & - & - & - & - & - & - & - & - & - & - & 1.00 & 1.00 & 1.00 & 1.00 & 0.00 & 0.74 \\
\hline
\end{tabular}

a Total metal content, $\mathrm{M}=\mathrm{Sn}+\mathrm{Sb}+\mathrm{Pt}+\mathrm{Ru}$

b Adsorbed oxygen O-H (OAds.) to oxide-lattice oxygen M-O (Ooxid.) photoemission intensities ratio (corrected values from deconvoluted $\mathrm{O}(1 \mathrm{~s}), \mathrm{C}(1 \mathrm{~s})$ and $\mathrm{Ti}(2 \mathrm{p}-\mathrm{XPS}$ spectra): $\mathrm{IOH}$ $=[$ OAds. $]-[\mathrm{C}-\mathrm{OH}]$ and $\mathrm{IOM}=[$ Ooxid. $]-2[\mathrm{Ti}]$.
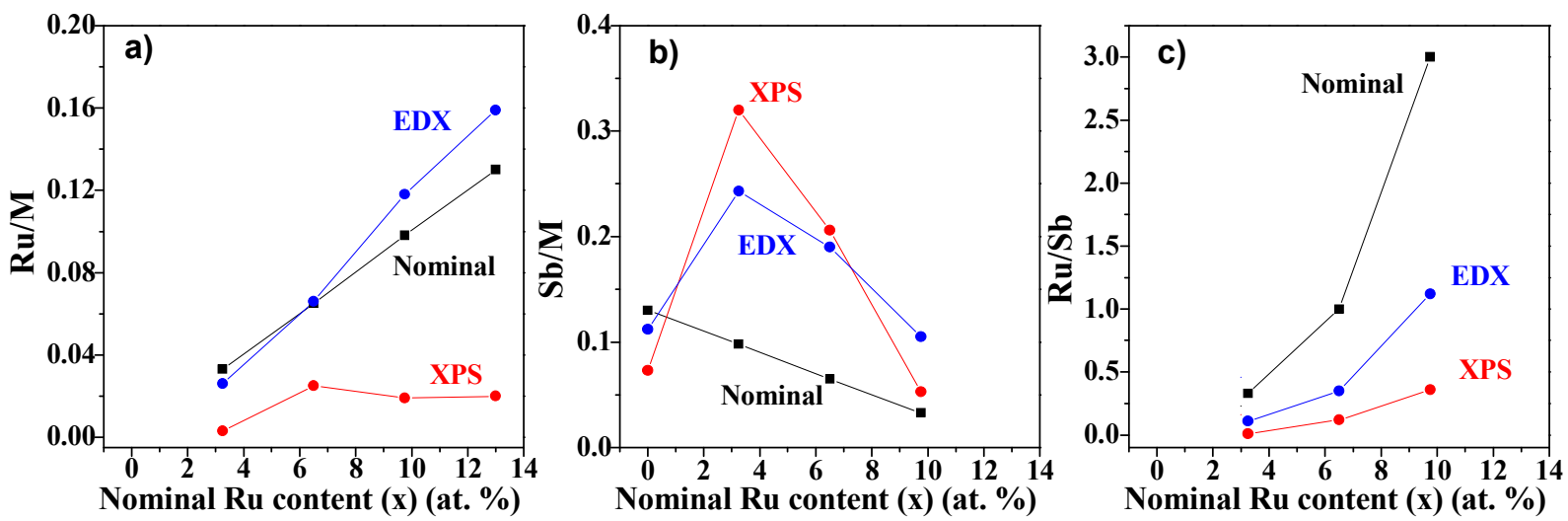

Figure 3. EDX and XPS atomic ratios relative to the total metal content $(\mathrm{M})$ of $\mathrm{SnO}_{2}-\mathrm{Sb}(13-\mathrm{x})$ $\mathrm{Pt}-\mathrm{Ru}(\mathrm{x}) / \mathrm{Ti}$ electrodes as a function of the nominal $\mathrm{Ru}$ content: a) $\mathrm{Ru} / \mathrm{M}$; b) Sb/M and c) $\mathrm{Ru} / \mathrm{Sb}$. 
In the same manner, the similarity between nominal and EDX-obtained $\mathrm{Ru} / \mathrm{M}$ ratios shows that the amount of $\mathrm{Ru}$ introduced in the $\mathrm{SnO}_{2}-\mathrm{Sb}(13-\mathrm{x})-\mathrm{Pt}-\mathrm{Ru}(\mathrm{x}) / \mathrm{Ti}$ electrodes approaches quite well the desired one, whereas the surface $\mathrm{Ru}$ content (XPS ratio) remains almost constant and much lower than the nominal one (Fig. 3a). As shown in Fig. $3 \mathrm{~b}$ and Table 1, the introduction of a low $\mathrm{Ru}$ content $(\mathrm{x}=3.25$ at. \%) produces a marked enrichment in $\mathrm{Sb}$ and a marked depletion in $\mathrm{Sn}$, in both the bulk and the surface of the electrodes. A further increment in the Ru content gradually increases the $\mathrm{Sn} / \mathrm{M}$ ratio and reduces the $\mathrm{Sb} / \mathrm{M}$ ratio to values (for $\mathrm{x}=9.75$ at. $\%$ ) closer to those obtained in the absence of $\mathrm{Ru}(\mathrm{x}=0.00$ at. \%) (Table 1). On the other hand, the comparison among the nominal and EDX and XPS experimental Ru/Sb ratios (Fig. 3c.) shows that only about one third of $\mathrm{Sb}$ is replaced by $\mathrm{Ru}$. This may indicate that $\mathrm{Ru}$ does not effectively replace $\mathrm{Sb}$ in the mixed oxide, but it may replace $\mathrm{Sn}$ in the rutile-like lattice, hence explaining its depletion. Finally, the amount of Pt (bulk) introduced in the coatings is above (almost double) the nominal one, regardless of the Ru content (Table 1), while the Pt surface content varies above and below the nominal one with no clear trend. However, a clear surface depletion of Ru with respect to both its nominal and experimental bulk values is observed in the whole set of $\mathrm{SnO}_{2}$ $\mathrm{Sb}(13-\mathrm{x})-\operatorname{Pt}(3)-\mathrm{Ru}(\mathrm{x}) / \mathrm{Ti}$ electrodes.

\subsubsection{Surface chemical state.}

The $\mathrm{Sn}\left(3 \mathrm{~d}\right.$ ) spectra of the different $\mathrm{SnO}_{2}$-based electrodes (Fig. 4a) show two peaks at $487.0 \mathrm{eV}$ and $495.4 \mathrm{eV}$, typically assigned to the $\mathrm{Sn} 3 \mathrm{~d}_{3 / 2}$ and $3 \mathrm{~d}_{5 / 2}$ states from the spin-orbital splitting, ${ }^{41,42}$ which may correspond to either $\mathrm{SnO}, \mathrm{SnO}_{2}$ or $\mathrm{Sn}(\mathrm{OH})_{\mathrm{x}}$ species. ${ }^{41,42}$ Since the XPS spectrum (not shown) does not exhibit any $\operatorname{Sn}(5 \mathrm{~s})$ peak attributed to $\mathrm{SnO}$, the $\mathrm{Sn}(3 \mathrm{~d})$ signals are assigned to $\mathrm{SnO}_{2} \cdot{ }^{41}$ In agreement with data previously reported, ${ }^{43}$ the incorporation of low $\mathrm{Pt}$ doping levels in mixed Sn-Sb oxides (Fig. $4 \mathrm{a}, \mathrm{x}=0.00 \%$ ) does not produce any change neither in 
the $\operatorname{Sn}(3 \mathrm{~d})$ core-level binding energy nor in their energy width and symmetry with respect to undoped materials. This result suggests that the electronic structure of the $\mathrm{SnO}_{2}$ lattice is unaffected by Pt atoms at such a low content. ${ }^{41}$ The Pt $4 \mathrm{f}_{7 / 2}$ core level photoemission peak observed for the $\mathrm{SnO}_{2}-\mathrm{Sb}(13-\mathrm{x})-\mathrm{Pt}-\mathrm{Ru}(\mathrm{x}) / \mathrm{Ti}$ electrodes can be separated into three main contributions and three satellite peaks (Fig. 4c). These peaks are associated with the presence of metallic platinum $(\mathrm{Pt}(0))$ and $\mathrm{Pt}(\mathrm{II})$ and $\mathrm{Pt}(\mathrm{IV})$ species), and their relative concentration was found to vary randomly among the different electrodes. ${ }^{43}$

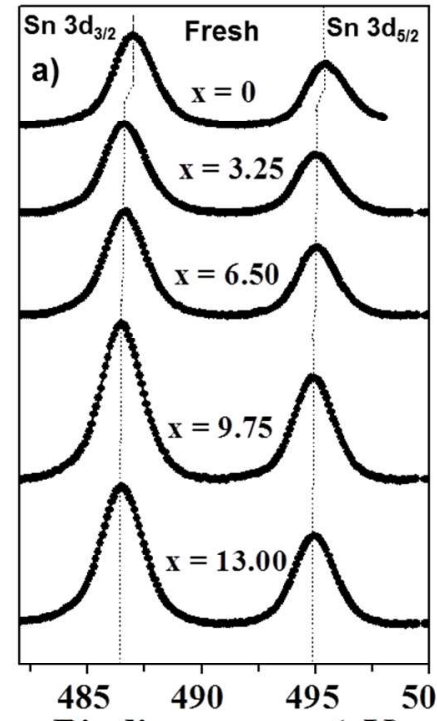

Binding energy $(\mathrm{eV})$

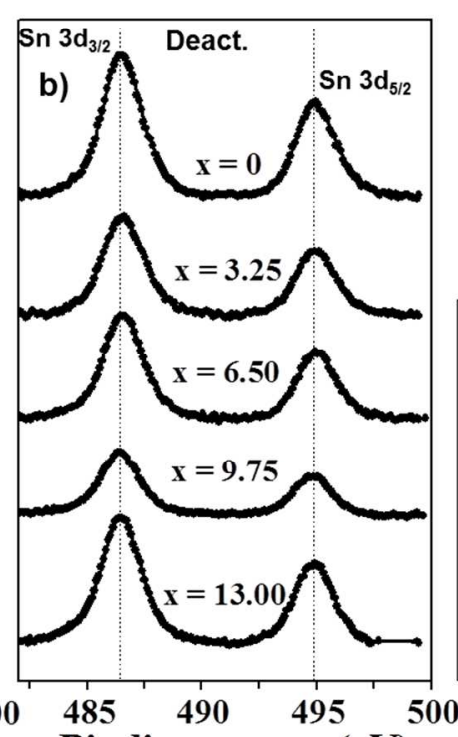

Binding energy $(\mathrm{eV})$
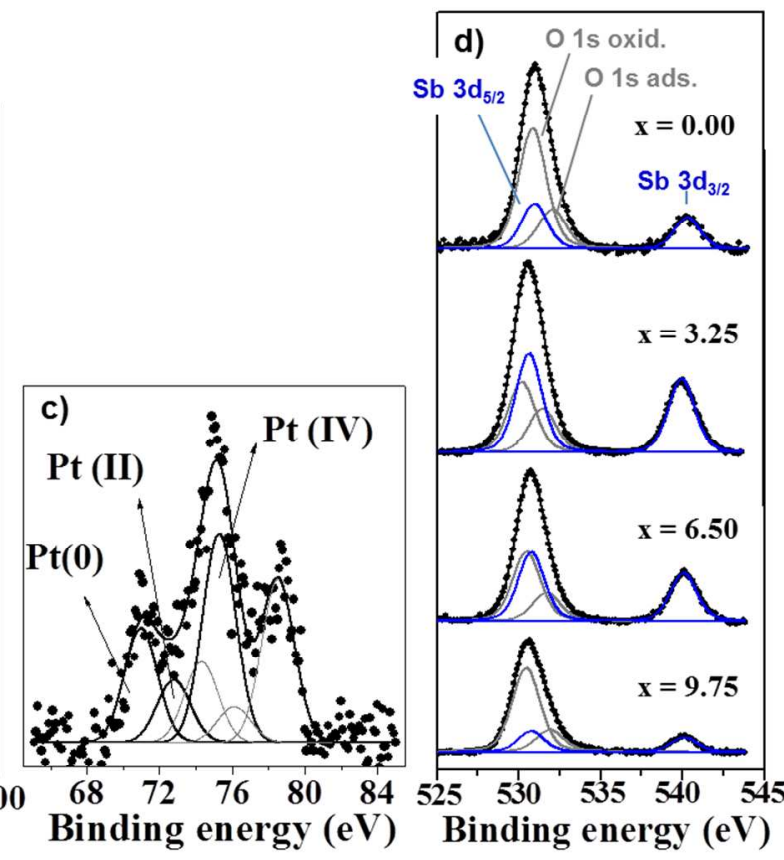

Binding energy $(\mathrm{eV})$

Figure 4. $\mathrm{Sn}(3 \mathrm{~d})$ XPS spectra of (a) fresh $\mathrm{SnO}_{2}-\mathrm{Sb}(13-\mathrm{x})-\mathrm{Pt}-\mathrm{Ru}(\mathrm{x}) / \mathrm{Ti}$ electrodes, (b) deactivated $\mathrm{SnO}_{2}-\mathrm{Sb}(13-\mathrm{x})-\mathrm{Pt}-\mathrm{Ru}(\mathrm{x}) / \mathrm{Ti}$ electrodes; (c) $\mathrm{Pt}(4 \mathrm{f})$ XPS spectrum of a fresh $\mathrm{SnO}_{2}-\mathrm{Sb}-\mathrm{Pt} / \mathrm{Ti}$ electrode; and (d) $\mathrm{Sb}(3 \mathrm{~d})$ XPS spectra of fresh $\mathrm{SnO}_{2}-\mathrm{Sb}(13-\mathrm{x})-\mathrm{Pt}-\mathrm{Ru}(\mathrm{x}) / \mathrm{Ti}$ electrodes. 
On the other hand, the XPS spectra in the energy region between $525 \mathrm{eV}$ and $544 \mathrm{eV}$ revealed the presence of another two peaks (Fig. 4d). The peak at $540 \mathrm{eV}$ corresponds to the $\mathrm{Sb} 3 \mathrm{~d}_{3 / 2}$ signal, while that at $531 \mathrm{eV}$ is composed of the $\mathrm{O}(1 \mathrm{~s})$ (at $531 \mathrm{eV}$ ) together with the $\mathrm{Sb} 3 \mathrm{~d}_{5 / 2}$ signals. The deconvolution of the $\mathrm{Sb} 3 \mathrm{~d}_{3 / 2}$ signal revealed that the largest fraction of $\mathrm{Sb}$ in the $\mathrm{SnO}_{2}-\mathrm{Sb} / \mathrm{Ti}$ electrode has a 5+ oxidation state (contribution at $530.6 \mathrm{eV}^{28,43-46}$ ), although $\mathrm{Sb}$ (III) (22 at. \%) was also observed in this electrode. ${ }^{41,46}$ Some authors have indicated that Sb(III) is preferentially located on the surface and grain boundaries of the $\mathrm{SnO}_{2}-\mathrm{Sb}$ film. ${ }^{41,46}$ On the contrary, the $\mathrm{Sb} 3 \mathrm{~d}_{3 / 2}$ peak in $\mathrm{SnO}_{2}-\mathrm{Sb}(13-\mathrm{x})-\mathrm{Pt}-\mathrm{Ru}(\mathrm{x}) / \mathrm{Ti}$ electrodes (Fig. 4d) can be satisfactorily fitted with a single photoemission contribution corresponding to $\mathrm{Sb}$ atoms in a $5+$ charge state (usually represented as $\mathrm{SnO}_{2}-\mathrm{Sb}_{2} \mathrm{O}_{5}$ ). This is in agreement with the results of Montilla et al., ${ }^{43}$ who found that the presence of a small Pt content on the electrode surface promotes the complete oxidation of $\mathrm{Sb}$ in the oxide coating. With the theoretical peak intensity ratio and splitting of the $\mathrm{Sb}(3 \mathrm{~d})$ spin-orbit doublet (1.44 and $10.7 \mathrm{eV}$, respectively), we used the $\mathrm{Sb} 3 \mathrm{~d}_{3 / 2}$ peak to correct the $\mathrm{O}(1 \mathrm{~s})$ photoemission line from the $\mathrm{Sb} 3 \mathrm{~d}_{5 / 2}$ interference. $^{43,45}$ After the correction, the $\mathrm{O}(1 \mathrm{~s})$ signal could be deconvoluted into two peaks (Fig. 4d). The major peak at $530.9 \mathrm{eV}$ is associated with oxygen directly bonded to a metal atom (metal oxides) and the minor one $(532.1 \mathrm{eV})$ is related to oxygen bonded to metal hydroxides or hydrated species on the surface. $^{41,43}$ 

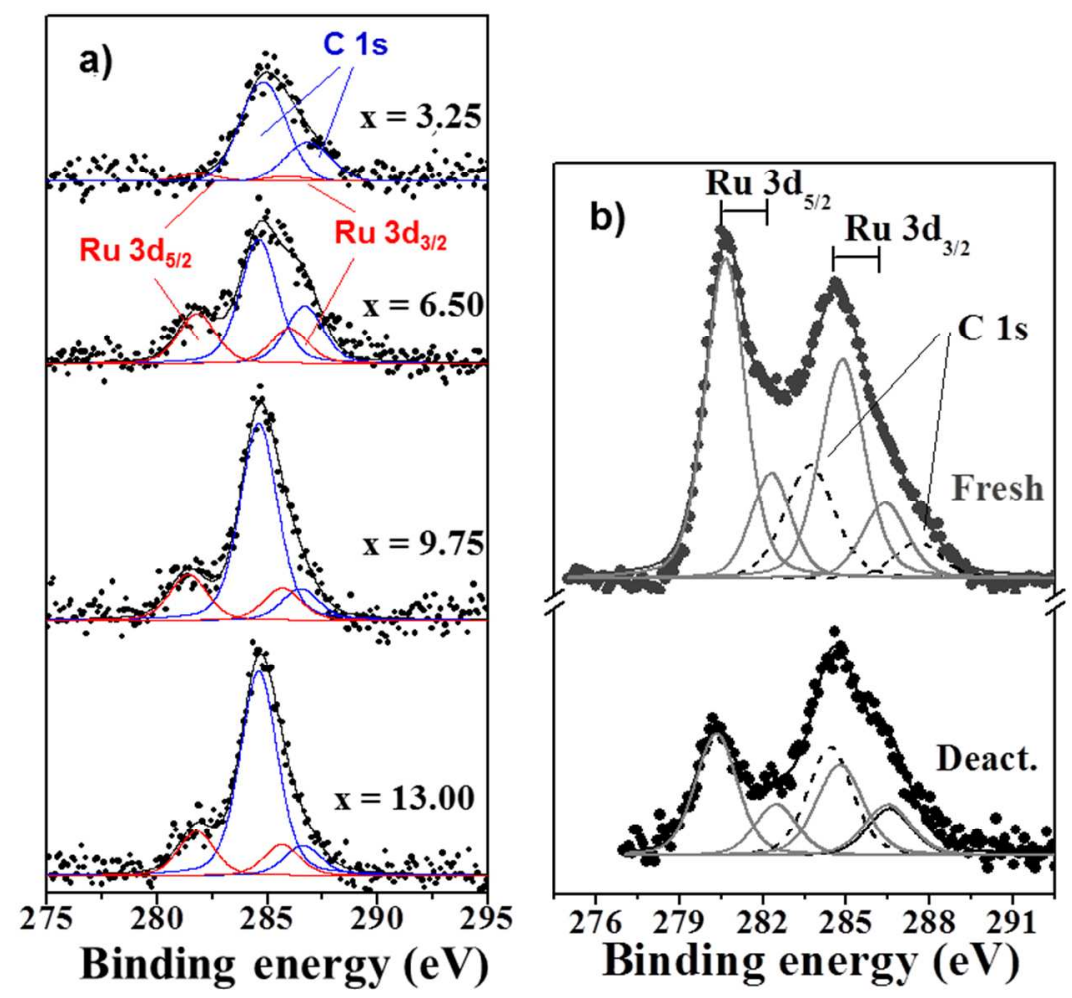

Figure 5. $\mathrm{Ru}(3 \mathrm{~d})$ XPS spectra of (a) fresh $\mathrm{SnO}_{2}-\mathrm{Sb}(13-\mathrm{x})-\mathrm{Pt}-\mathrm{Ru}(\mathrm{x}) / \mathrm{Ti}$ electrodes and (b) fresh and deactivated $\mathrm{RuO}_{2} / \mathrm{Ti}$ electrodes.

The introduction of $\mathrm{Ru}\left(\mathrm{SnO}_{2}-\mathrm{Sb}(13-\mathrm{x})-\mathrm{Pt}-\mathrm{Ru}(\mathrm{x}) / \mathrm{Ti}\right.$ electrodes $)$ leads to the appearance of $\mathrm{Ru}$ $3 \mathrm{~d}_{5 / 2}$ and $3 \mathrm{~d}_{3 / 2}$ peaks at $282.3 \mathrm{eV}$ and $284.8 \mathrm{eV}$, respectively, which overlap with the region of $\mathrm{C}(1 \mathrm{~s})$ core level spectra of adventitious carbon (Fig. 5a). These two peaks are observed also in the spectrum of pure $\mathrm{RuO}_{2} / \mathrm{Ti}$ electrode (Fig. 5b) and are assigned to ruthenium (IV) oxide. ${ }^{47}$ Moreover, the progressive substitution of $\mathrm{Sb}$ by $\mathrm{Ru}$ in the nominal composition causes a band shift of $\operatorname{Sn} 3 d_{5 / 2}$ and $3 d_{3 / 2}$ peaks towards lower binding energies (Fig. 4a), whereas it does not cause a significant effect on the binding energy of $\mathrm{Sb} 3 \mathrm{~d}_{3 / 2}$ and $\mathrm{O}(1 \mathrm{~s})$ (Fig. 4d). These results may indicate that there is no interaction between $\mathrm{Sb}$ and $\mathrm{Ru}$ species, but instead, a strong chemical interaction between $\mathrm{Sn}(\mathrm{IV})$ and $\mathrm{Ru}(\mathrm{IV})$ cations occurs.

\subsubsection{Structural characterization.}


Fig. 6a shows the XRD diffraction patterns of the as-prepared $\mathrm{SnO}_{2}-\mathrm{Sb}(13-\mathrm{x})-\mathrm{Pt}-\mathrm{Ru}(\mathrm{x}) / \mathrm{Ti}$ electrodes. For comparison purposes, the XRD diffraction peaks of $\mathrm{RuO}_{2}$ and the Ti substrate are also included in this figure. The XRD diffractogram of the $\mathrm{SnO}_{2}-\mathrm{Sb}-\mathrm{Pt} / \mathrm{Ti}$ electrode is very similar to that of $\mathrm{SnO}_{2}$ - $\mathrm{Sb}$ /Ti (Fig. S2) with sharp peaks corresponding to the tetragonal rutilelike structure of $\mathrm{SnO}_{2}$ cassiterite. ${ }^{44}$ In a similar way, the observed XRD of the $\mathrm{RuO}_{2} / \mathrm{Ti}$ electrode (Fig. 6a) is also in agreement with the tetragonal rutile-like structure of $\mathrm{RuO}_{2}$ (Table 2). The replacement of $\mathrm{Sb}$ by $\mathrm{Ru}$ in the nominal composition does not result in the appearance of new diffraction peaks. However, the progressive incorporation of $\mathrm{Ru}$ into the oxide coating shifts the $\mathrm{SnO}_{2}$ diffraction peaks to higher Bragg angles, although this increase is small above $\mathrm{x}=9.75$ at. $\%$ (Fig 6b). As it is shown in Table 2, the increase in Bragg angles involves a gradual reduction in the unit-cell parameters and, consequently, in the volume of the unit-cell. This indicates that $\mathrm{Ru}(\mathrm{IV})$, which has a smaller ionic radius than $\operatorname{Sn}(\mathrm{IV})(0.76 \AA$ against $0.83 \AA$ ), is incorporated into the cationic $\mathrm{SnO}_{2}$ sublattice to form a solid solution $\left(\mathrm{Ru}_{\delta} \mathrm{Sn}_{1-\delta}\right) \mathrm{O}_{2}$, leading to the contraction of the rutile-like lattice. ${ }^{39,47,48}$ The formation of such a solid solution is strongly supported by the marked effect of $\mathrm{Ru}$ in the $\mathrm{Sn}(3 \mathrm{~d}$ ) binding energies (Fig. 4a) . Nevertheless, the diffraction peaks for $\mathrm{x}=9.75$ at. $\%$ start to display certain asymmetry that becomes more important at the highest $\mathrm{Ru}$ content. This asymmetry is more noticeable in the $\mathrm{SnO}_{2}-\mathrm{Ru} / \mathrm{Ti}$ electrode prepared in the same conditions (Fig. 6c). The deconvolution of these diffraction peaks reveals that the asymmetry corresponds to the formation of $\mathrm{RuO}_{2}$ phase. Both the appearance of peak asymmetry and the leveling off in the Bragg angle shift from $\mathrm{x}=9.75$ at. $\%$ suggest that the mixed oxide reaches the solubility limit of $\mathrm{Ru}$ cations into the rutile-like $\mathrm{SnO}_{2}$ lattice, so $\mathrm{Ru}$ starts to segregate as $\mathrm{RuO}_{2}$ phase. 

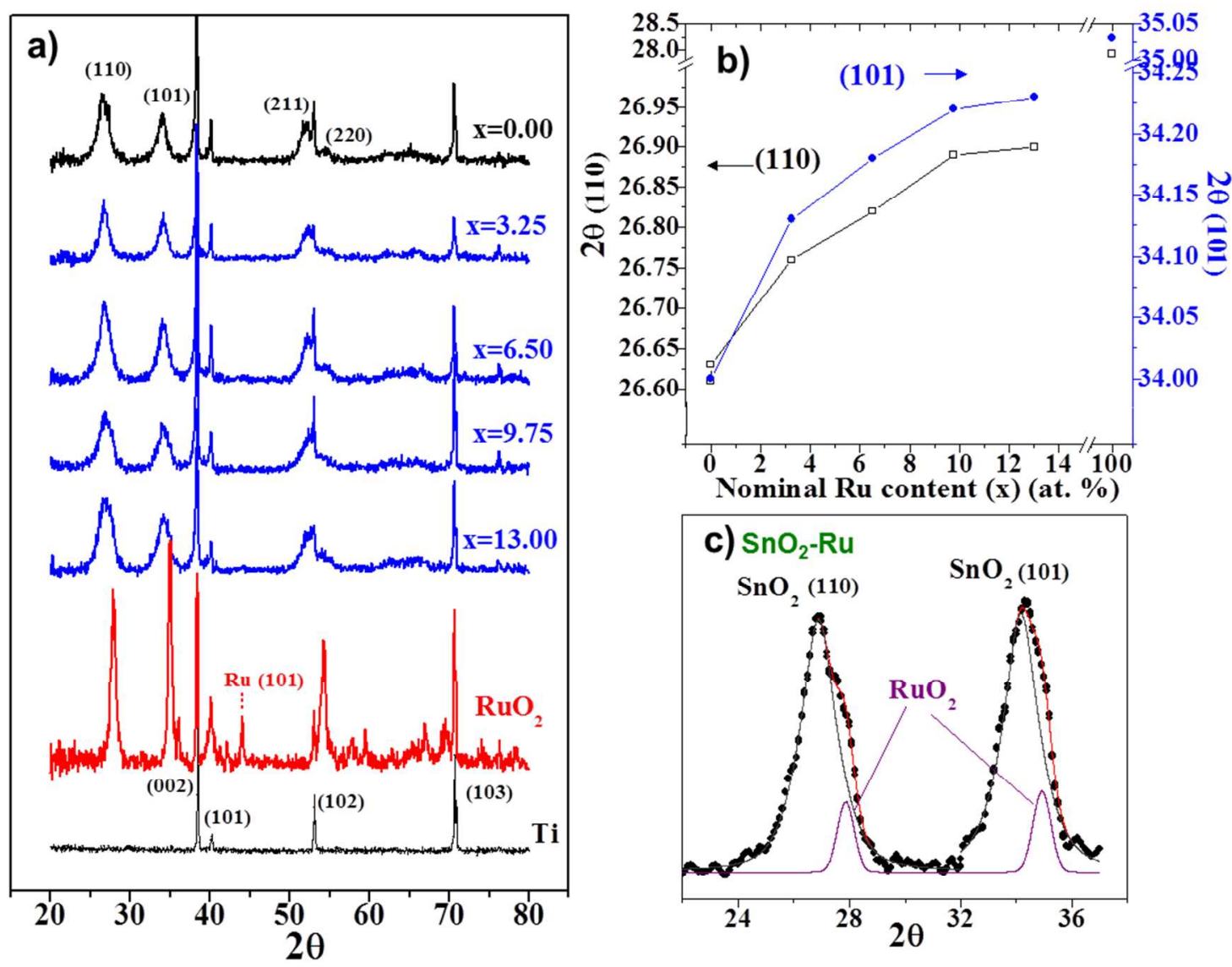

Figure 6. (a) X-ray diffraction patterns of fresh $\mathrm{SnO}_{2}-\mathrm{Sb}(13-\mathrm{x})-\mathrm{Pt}-\mathrm{Ru}(\mathrm{x}) / \mathrm{Ti}$ electrodes and $\mathrm{RuO}_{2} / \mathrm{Ti}$ electrode; (b) (110) and (101) peak position as a function of the nominal Ru content; (c) deconvolution of (110) and (101) peaks for $\mathrm{SnO}_{2}-\mathrm{Ru} / \mathrm{Ti}$ electrode.

In spite of the structural changes, Table 3 shows that the addition of the doping metals like $\mathrm{Ru}$, $\mathrm{Sb}$ or $\mathrm{Pt}$, produces almost no effect in the average crystallite size of the different oxides, which ranges between 5.2-5.8 $\mathrm{nm}$. This crystallite size is in agreement with the average particle size (around 5-10 nm), observed by TEM (Fig. 7). The figure includes TEM images of $\mathrm{SnO}_{2}-\mathrm{Sb}(13-$ $\mathrm{x})-\mathrm{Pt}-\mathrm{Ru}(\mathrm{x})$ oxides with different $\mathrm{Ru}$ contents. The oxides consist of highly aggregated particles with ellipsoidal-like morphology, in agreement with other transition metal oxides prepared by thermal decomposition. ${ }^{49}$ In particular, specific phases characteristic of $\mathrm{Sb}, \mathrm{Pt}$, and $\mathrm{Ru}$ dopants 
were not distinguished, in accordance with XRD results, and the lack of significant differences among the three images reveals that the introduction of $\mathrm{Ru}$ in the mixed solid solution $\left(\mathrm{Ru}_{\delta} \mathrm{Sn}_{1}\right.$ $\left.{ }_{\delta}\right) \mathrm{O}_{2}$ causes practically no effect in the microstructure of the oxides.

Table 3. Lattice parameters $(\mathrm{a}=\mathrm{b}$ and $\mathrm{c})$ of the rutile-like structure, unit cell volume $(\mathrm{V})$ and crystallite size $\left(\mathrm{d}_{\mathrm{c}}\right)$ for the as-prepared electrodes calculated from XRD patterns.

\begin{tabular}{|c|c|c|c|c|c|}
\hline Electrode & $(\mathrm{x})$ & $\mathrm{a}(\AA)^{\mathrm{b}}$ & $\mathrm{c}(\AA)^{\mathrm{b}}$ & $\mathrm{V}\left(\AA^{3}\right)^{\mathrm{b}}$ & $\mathrm{d}_{\mathrm{c}}^{\mathrm{c}}(\mathrm{nm})$ \\
\hline $\mathrm{SnO}_{2}$, cassiterite $^{\mathrm{a}}$ & - & 4.740 & 3.190 & 71.7 & - \\
\hline $\mathrm{SnO}_{2}-\mathrm{Sb} / \mathrm{Ti}$ & - & 4.734 & 3.173 & 71.1 & 5.6 \\
\hline \multirow{5}{*}{$\begin{array}{c}\mathrm{SnO}_{2-} \\
\mathrm{Sb}(13-\mathrm{x})- \\
\mathrm{Pt}-\mathrm{Ru}(\mathrm{x}) / \mathrm{Ti}\end{array}$} & 0.00 & 4.730 & 3.173 & 71.0 & 5.7 \\
\hline & 3.25 & 4.708 & 3.161 & 70.1 & 5.8 \\
\hline & 6.50 & 4.697 & 3.154 & 69.6 & 5.5 \\
\hline & 9.75 & 4.687 & 3.152 & 69.2 & 5.2 \\
\hline & 13.00 & 4.685 & 3.147 & 69.1 & 5.2 \\
\hline $\mathrm{SnO}_{2}-\mathrm{Ru} / \mathrm{Ti}$ & - & 4,685 & 3,148 & 69.1 & 5.5 \\
\hline $\mathrm{RuO}_{2} / \mathrm{Ti}$ & - & 4.504 & 3.113 & 63.1 & 13.2 \\
\hline $\mathrm{RuO}_{2}{ }^{\mathrm{a}}$ & - & 4.499 & 3.107 & 62.9 & - \\
\hline
\end{tabular}

${ }^{\mathrm{a}}$ JCPS-International Centre for Diffraction Data.

${ }^{\mathrm{b}}$ Lattice parameters were calculated with the Bragg's equation.

${ }^{c}$ Average crystallite size determined from (110), (101), (211) and (220) $\mathrm{SnO}_{2}$-phase reflections and Scherrer's equation. The width of the deconvoluted $\mathrm{SnO}_{2}$ phase reflection was considered where segregation of $\mathrm{RuO}_{2}$ occurs. 

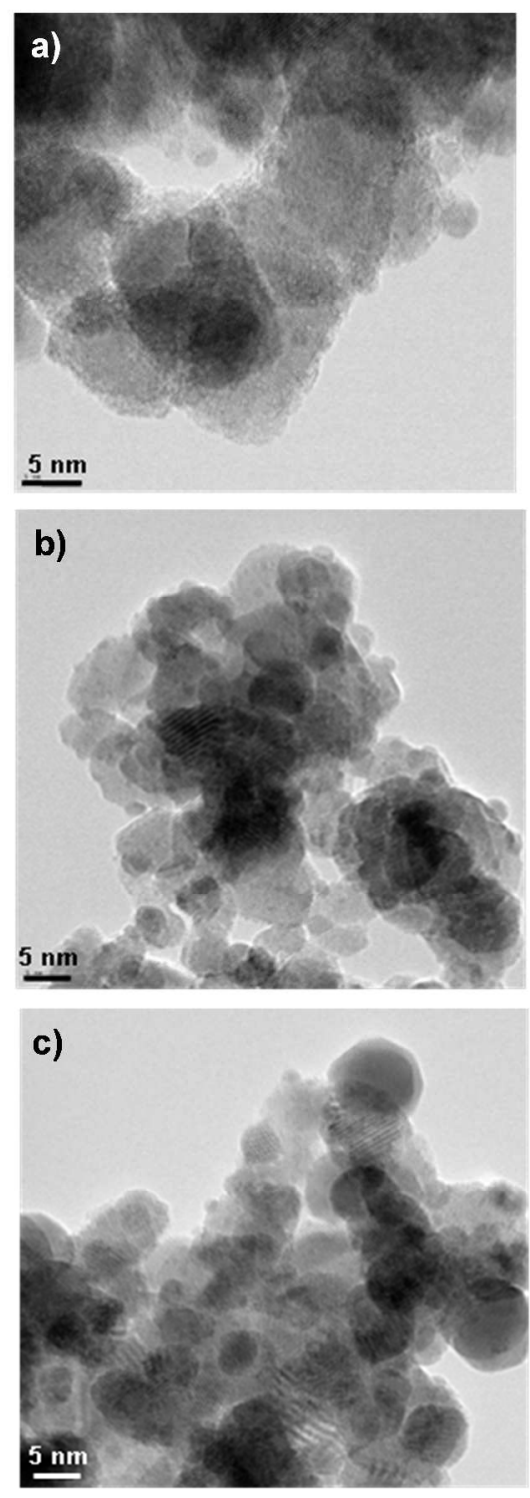

Figure 7. TEM images of fresh $\mathrm{SnO}_{2}-\mathrm{Sb}(13-\mathrm{x})-\mathrm{Pt}-\mathrm{Ru}(\mathrm{x}) / \mathrm{Ti}$ electrodes: (a) $\mathrm{x}=0.00$ at. \% $\mathrm{Ru}$; (b) $\mathrm{x}=6.50$ at. $\% \mathrm{Ru} ;(\mathrm{c}) \mathrm{x}=9.75$ at. $\% \mathrm{Ru}$.

\subsection{Electrochemical measurements}

\subsubsection{Electrochemical behavior.}

Fig. 8 shows the voltammetric response of the as-synthesized electrodes in alkaline medium. The voltammogram of $\mathrm{SnO}_{2}$-Sb/Ti electrode (Fig. 8a) shows no oxidation/reduction peaks and a 
sharp current rise, corresponding to the oxygen evolution reaction (OER), at potentials above 1.8 V. These features are common to non-active oxides. In the presence of $\mathrm{Pt}(\mathrm{x}=0.00$ at. \%) (Fig. $8 \mathrm{~b}$ ), the onset of the OER is shifted to lower potentials (around 1.7 V) and the voltammogram includes a broad oxidation peak (between 0.7 and $1.4 \mathrm{~V}$ ) and a much better-defined reduction counterpart (at ca. $0.65 \mathrm{~V}$ ) attributed to the formation and reduction of surface platinum oxides $\left(\mathrm{Pt} / \mathrm{PtO}_{\mathrm{x}}\right)\left(\mathrm{A}_{1} / \mathrm{C}_{1}\right)^{28}$
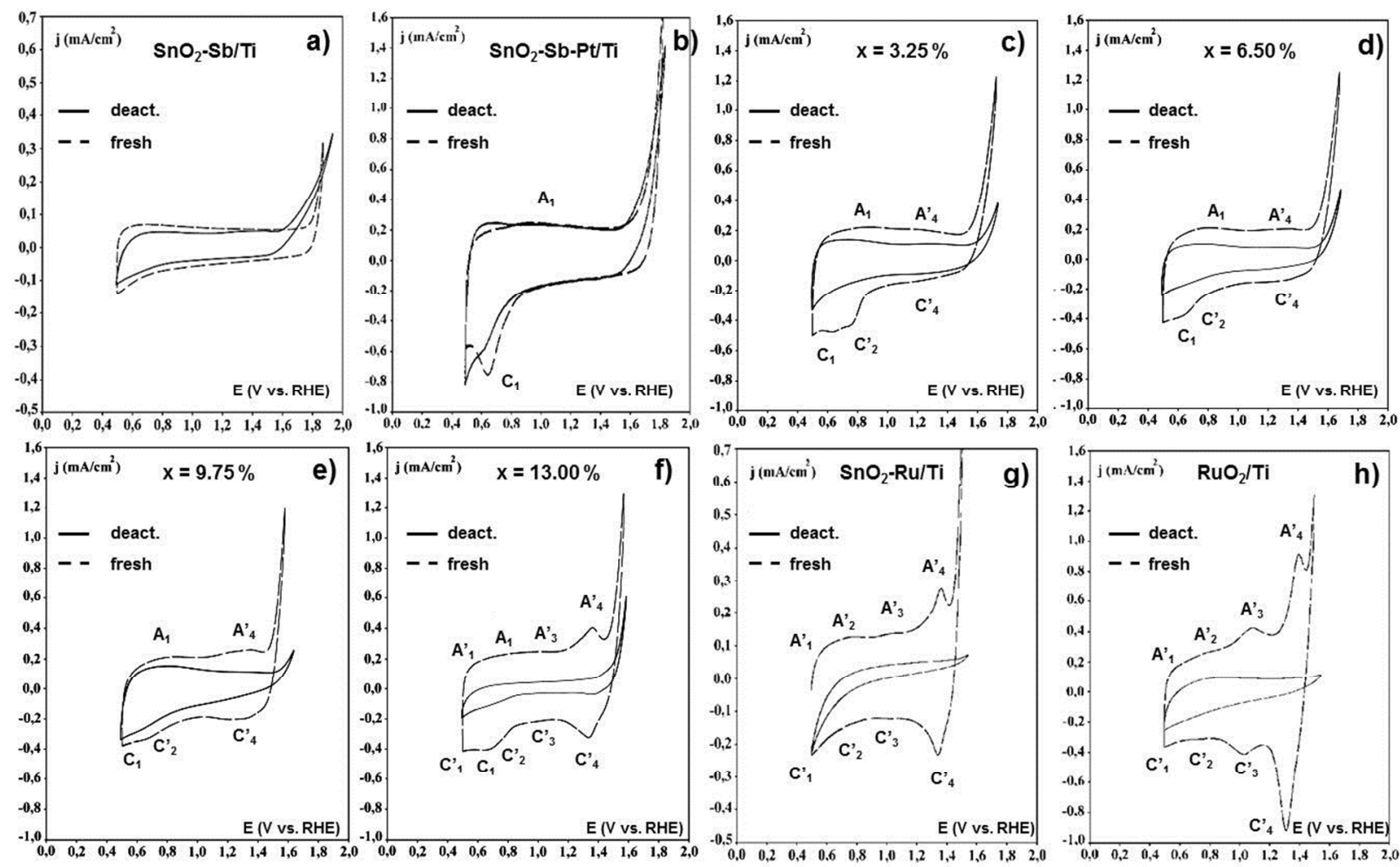

Figure 8. Steady cyclic voltammograms of fresh and deactivated electrodes in a $0.1 \mathrm{M} \mathrm{NaOH}$ solution, (a) $\mathrm{SnO}_{2}-\mathrm{Sb} / \mathrm{Ti}$ electrode, $\mathrm{SnO}_{2}-\mathrm{Sb}(13-\mathrm{x})-\mathrm{Pt}-\mathrm{Ru}(\mathrm{x}) / \mathrm{Ti}$ electrodes with (b) $\mathrm{x}=0.00$ at. $\%,\left(\right.$ c) $x=3.25$ at. $\%$, (d) $x=6.50$ at. $\%$, (e) $x=9.75$ at. $\%$, (f) $x=13.00$ at. $\%,(g) \mathrm{SnO}_{2}-\mathrm{Ru} / \mathrm{Ti}$ electrode and (h) $\mathrm{RuO}_{2} / \mathrm{Ti}$ electrode; $v=20 \mathrm{mV} \mathrm{s}^{-1}$. 
The gradual introduction of $\mathrm{Ru}$ in $\mathrm{SnO}_{2}$-based electrodes (Fig. $8 \mathrm{c}-\mathrm{h}, \mathrm{g}$ ) results in the appearance of various redox couples associated with the surface transitions of $\mathrm{Ru}$ in $\mathrm{RuO}_{2}$ electrodes (Fig. 8h): i) $\mathrm{Ru}(\mathrm{II}) \leftrightarrow \mathrm{Ru}(\mathrm{III})\left(\mathrm{A}_{1}^{\prime} / \mathrm{C}_{1}^{\prime}\right)$, ii) $\mathrm{Ru}(\mathrm{III}) \leftrightarrow \mathrm{Ru}(\mathrm{IV})\left(\mathrm{A}_{2}^{\prime} / \mathrm{C}_{2}\right)$, iii) $\mathrm{Ru}(\mathrm{IV}) \leftrightarrow \mathrm{Ru}(\mathrm{VI})\left(\mathrm{A}_{3}^{\prime} / \mathrm{C}_{3}^{\prime}\right)$ and iv) $\mathrm{Ru}(\mathrm{VI}) \leftrightarrow \mathrm{Ru}(\mathrm{VII})\left(\mathrm{A}_{4}{ }_{4} / \mathrm{C}_{4}\right) .{ }^{47,50}$ The current of these peaks increases with the $\mathrm{Ru}$ content. Furthermore, the onset potential of OER is shifted by about $0.1 \mathrm{~V}$ to less positive potentials than the observed for $\mathrm{SnO}_{2}-\mathrm{Sb}-\mathrm{Pt} / \mathrm{Ti}$ electrode due to the electrocatalytic effect of $\mathrm{Ru}$ on the OER.

Table 3. Service life (SL) and service life efficiency (SLE), specific capacitance, roughness factor (Rf) and electrochemical porosity $\left(\mathrm{P}_{\mathrm{e}}\right)$ for the as-prepared electrodes in $0.1 \mathrm{M} \mathrm{NaOH}$ solution.

\begin{tabular}{|c|c|c|c|c|c|c|c|c|c|c|}
\hline & & SL & SLE & \multicolumn{5}{|c|}{ Specific Capacitance $\left(\mathrm{mF} \mathrm{cm}^{-2}\right)$} & \multirow{2}{*}{ Rf } & \multirow{2}{*}{$\frac{\mathrm{P}_{\mathrm{e}}}{\text { Nom. }}$} \\
\hline Electrode & $(\mathrm{x})$ & (h) & $\left(\mathrm{A} \mathrm{h} \mathrm{mg} \mathrm{g}^{-1}\right)$ & $0.55 \mathrm{~V}$ & $0.75 \mathrm{~V}$ & $0.95 \mathrm{~V}$ & $1.15 \mathrm{~V}$ & $1.35 \mathrm{~V}$ & & \\
\hline $\mathrm{SnO}_{2}-\mathrm{Sb} / \mathrm{Ti}$ & - & 0.6 & 0.2 & 3.1 & 2.6 & 2.4 & 2.1 & 2.0 & 389 & 0.09 \\
\hline \multirow{5}{*}{$\begin{array}{c}\mathrm{SnO}_{2^{-}} \\
\mathrm{Sb}(13-\mathrm{x})- \\
\mathrm{Pt}-\mathrm{Ru}(\mathrm{x}) / \mathrm{Ti}\end{array}$} & 0.00 & 72 & 22 & 3.7 & 3.4 & 3.0 & 2.7 & 2.5 & 464 & 0.34 \\
\hline & 3.25 & 189 & 63 & 7.4 & 7.3 & 6.7 & 6.1 & 5.9 & 931 & 0.33 \\
\hline & 6.50 & 210 & 75 & 7.2 & 7.2 & 6.7 & 6.3 & 6.3 & 900 & 0.32 \\
\hline & 9.75 & 212 & 106 & 6.9 & 7.0 & 6.7 & 6.6 & 7.1 & 863 & 0.29 \\
\hline & 13.00 & 86 & 25 & 6.1 & 6.1 & 5.4 & 5.9 & 8.5 & 761 & 0.21 \\
\hline $\mathrm{SnO}_{2}-\mathrm{Ru} / \mathrm{Ti}$ & - & 116 & 35 & 3.4 & 3.5 & 3.5 & 3.6 & 8.6 & 450 & 0.10 \\
\hline $\mathrm{RuO}_{2} / \mathrm{Ti}$ & - & 640 & 181 & 6.8 & 7.5 & 8.5 & 12.1 & 20.7 & 85 & 0.19 \\
\hline
\end{tabular}

Service life (SL) and service life efficiency (SLE, total charge passed per unit mass of deposited oxide) at $0.5 \mathrm{~A} \mathrm{~cm}^{-2}$ in $1 \mathrm{M} \mathrm{NaOH}$ solution. The rest of parameters were obtained from voltammetric measurements in $0.1 \mathrm{M} \mathrm{NaOH}$.

The capacitance of the electrodes in $0.1 \mathrm{M} \mathrm{NaOH}$ was measured at different potentials (Table 3) by cyclic voltammetry at various scan rates according to a previously reported procedure. ${ }^{28,33,51}$ The capacitance of $\mathrm{SnO}_{2}-\mathrm{Sb} / \mathrm{Ti}$ and $\mathrm{SnO}_{2}-\mathrm{Sb}-\mathrm{Pt} / \mathrm{Ti}(\mathrm{x}=0.00$ at. \%) electrodes in alkaline 
electrolyte decreases with the potential, showing the characteristic behavior for a n-type semiconductor, whereas that of the $\mathrm{RuO}_{2} / \mathrm{Ti}$ electrode increases with the potential, characteristic of p-type semiconductors. The effect of $\mathrm{Ru}$ incorporate in $\mathrm{SnO}_{2}-\mathrm{Sb}(13-\mathrm{x})-\mathrm{Pt}-\mathrm{Ru}(\mathrm{x}) / \mathrm{Ti}$ electrodes is manifested by an increase in capacitance even for low Ru content. These results highlight the marked effect of $\mathrm{Ru}$ on the electrochemical response of $\mathrm{SnO}_{2}$-based electrodes in alkaline conditions.

The capacitance values provide information on the real, electrochemically-active, surface area of the electrodes through the so-called roughness factor $(\mathrm{Rf})$, which is defined as the real surface area per geometric area of electrode $\left(2 \mathrm{~cm}^{2}\right)$ and is one of the electrocatalytic activitydetermining factors. The values of $\mathrm{Rf}$ were estimated from the experimental capacitance values at $0.55 \mathrm{~V}$ and the specific capacitance of $\mathrm{SnO}_{2}$-based $(8 \mu \mathrm{F} \mathrm{cm})^{-2}$ and $\left.\mathrm{RuO}_{2}(80 \mu \mathrm{F} \mathrm{cm})^{-2}\right)^{53}$ electrodes. The introduction of $\mathrm{Ru}$ (Fig. 9a) produces an increase in the roughness factor at 0.55 $\mathrm{V}$ and the different voltammetric charges of the $\mathrm{SnO}_{2}-\mathrm{Sb}(13-\mathrm{x})-\mathrm{Pt}-\mathrm{Ru}(\mathrm{x}) / \mathrm{Ti}$ electrodes, reaching a maximum when $\mathrm{x}=3.25$ at. $\%$,. Then these parameters slightly decrease with the increase in $\mathrm{Ru}$ content.

The voltammetric charge $\left(\mathrm{q}^{*}\right)$ is another important parameter influenced by both the real surface area (geometric factors) and the specific electroactivity of the sites, which depends on the chemical composition of the oxide layers (electronic factors). The total $\left(\mathrm{q}_{\mathrm{TOT}}{ }^{*}\right)$, outer ( $\left.\mathrm{q}_{\text {out }}{ }^{*}\right)$ and inner $\left(\mathrm{q}_{\mathrm{IN}}{ }^{*}\right)$ voltammetric charges of the electrodes were measured by using the procedure described in the literature. ${ }^{51}$ These charges are related to the total, the most accessible and the less accessible (pores, cracks, grain boundaries, etc.) ${ }^{48}$ electroactive surface, respectively (Fig. 9a). These electrical charges show the same tendency as roughness factor. The so-called electrochemical porosity $\left(\mathrm{P}_{\mathrm{e}}\right)$ (Table 3 ), obtained from the inner charge to total charge ratio 
$\left(\mathrm{q}_{\mathrm{IN}} * / \mathrm{q}_{\mathrm{TOT}} *\right)$ also shows the same tendency. ${ }^{28,48}$ These trends are in good agreement with the morphology changes observed by SEM and suggest that, unlike in acid medium, ${ }^{33}$ the electrochemical response of these electrodes in $\mathrm{NaOH}$ solution is governed by geometric factors (i.e. by the surface area exposed to the electrolyte solution).
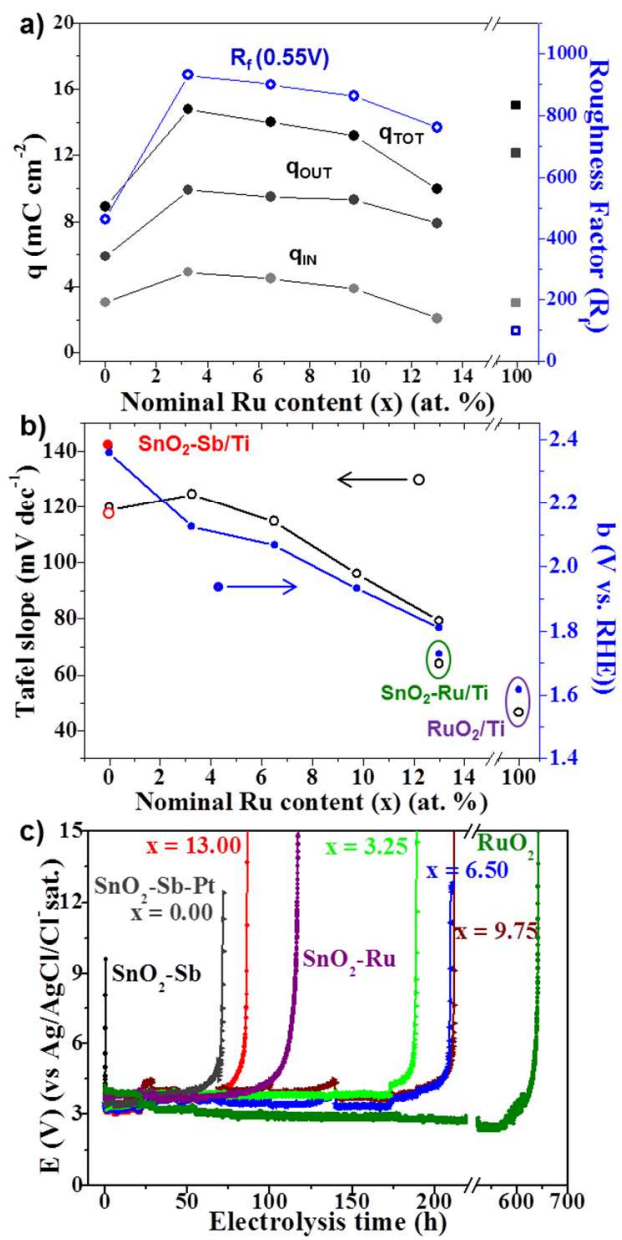

Figure 9. (a) Total $\left(\mathrm{q}_{\mathrm{TOT}}\right)$, outer ( $\left.\mathrm{q}_{\mathrm{OUT}}\right)$ and inner $\left(\mathrm{q}_{\mathrm{IN}}\right)$ charges and roughness factor for the $\mathrm{SnO}_{2}-\mathrm{Sb}(13-\mathrm{x})-\mathrm{Pt}-\mathrm{Ru}(\mathrm{x}) / \mathrm{Ti}$ electrodes and $\mathrm{RuO}_{2} / \mathrm{Ti}$ electrode as a function of the nominal $\mathrm{Ru}$ content; (b) Tafel slope and Tafel line y-intercept as a function of the nominal Ru content; and (c) Potential vs. electrolytsis time during service life tests for the different electrodes indicated in the figure. 


\subsubsection{Oxygen evolution reaction (OER).}

The electrocatalytic activity of the different electrodes in alkaline medium was evaluated from the linear region of their corresponding Tafel plots $\left(\log \mathrm{j}\right.$ vs. E) ${ }^{54}$ (see Supp. Info.-Fig. S3). The Tafel slopes provide relevant information on reaction mechanisms, whereas the y-intercept of the Tafel plot at $\mathrm{j}=0$ is related to the exchange current density $\left(\mathrm{j}_{0}\right)$, i.e. the intrinsic ability of an electrocatalyst to catalyze a reaction at $\eta=0 \mathrm{~V} .{ }^{54}$ Thus the lower the y-intercept value (b in Fig. 9b), the higher $\mathrm{j}_{0}$. As shown in Fig. $9 \mathrm{~b}, \mathrm{SnO}_{2}-\mathrm{Sb} / \mathrm{Ti}$ and $\mathrm{SnO}_{2}-\mathrm{Sb}-\mathrm{Pt} / \mathrm{Ti}(\mathrm{x}=0)$ electrodes exhibit a Tafel slope in alkaline conditions of around $120 \mathrm{mV} \mathrm{dec}{ }^{-1}$, which suggests a kinetic control by the adsorption of $\mathrm{OH}^{-}$according to the generally proposed OER mechanism. ${ }^{54}$ These Tafel slopes, together with the high values of $y$-intercept constant ( $b \approx 2.4 \mathrm{~V}$, Fig. $9 \mathrm{~b}$ ), are in close agreement with those found in the literature for $\mathrm{SnO}_{2}$-based electrodes ${ }^{28,48}$ and reflect their poor electrocatalytic activity towards the OER. As the Ru content in the oxide layer increases, the values of both constants decrease down to $80 \mathrm{mV} \mathrm{dec}^{-1}$ and $1.8 \mathrm{~V}$, respectively, for $\mathrm{x}=13.0$

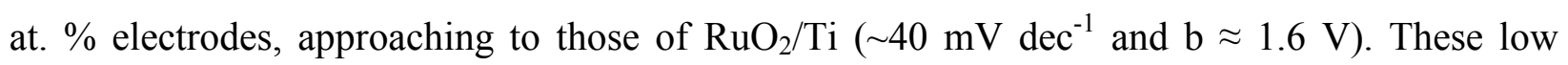
values are typical of $\mathrm{RuO}_{2}$ anodes and involve the electro-oxidation of the intermediate surface complex as the rate-determining step and a high electrocatalytic activity for the OER in these conditions. Thus, the decrease in Tafel constants indicates that the introduction of $\mathrm{Ru}$ in $\mathrm{SnO}_{2}-$ $\mathrm{Sb}-\mathrm{Pt} / \mathrm{Ti}$ electrodes gradually increases the electrocatalytic activity of the electrodes towards the OER, with a weakening of the metal-oxygen bond strength on the surface and a modification of the rate determining step. A similar electrocatalytic effect for $\mathrm{Ru}$ in $\mathrm{SnO}_{2}$-based anodes was also observed by other authors in both acidic ${ }^{33,48}$ and alkaline ${ }^{55}$ media. From Tafel results, it is suggested that the first step becomes more facilitated when $\mathrm{Sb}$ is replaced by $\mathrm{Ru}$ because of its higher redox activity, the induced change in the charge carrier mechanism, an increase in its 


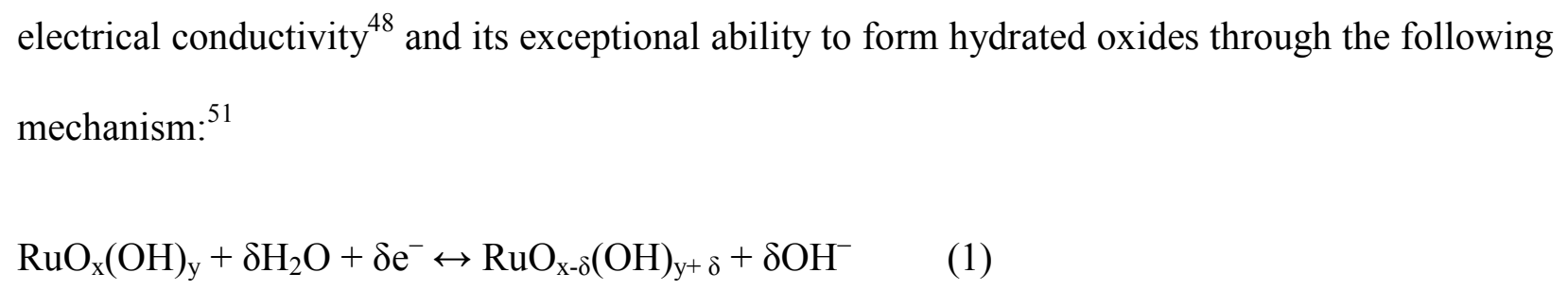

\subsection{Electrode stability and deactivation mechanism}

\subsubsection{Electrode stability.}

Fig. 9c depicts the evolution of the electrode potential with the electrolysis time upon anodic polarization at $0.5 \mathrm{~A} \mathrm{~cm}^{-2}$ in $1 \mathrm{M} \mathrm{NaOH}$. The electrode potential remains stable for a certain period of time, the so called service life, until it undergoes a sharp rise indicating deactivation. Table 3 summarizes the service life of the different electrodes, expressed as efficiency. The obtained results highlight the extremely short and long service life of the $\mathrm{SnO}_{2}-\mathrm{Sb}$ and $\mathrm{RuO}_{2}$ electrodes in $1 \mathrm{M} \mathrm{NaOH}$, respectively. Particularly, the value for $\mathrm{SnO}_{2}-\mathrm{Sb}$ is even much shorter than those reported for the deactivation process of Sb-doped $\mathrm{SnO}_{2}$ electrodes in acidic media. ${ }^{21,28}$ By contrast, the stability of $\mathrm{RuO}_{2}$ in alkaline conditions is much higher than in acid electrolytes $(1-3 \mathrm{~h}) .^{56}$

The introduction of a small amount of $\mathrm{Pt}\left(3\right.$ at. \%) in $\mathrm{SnO}_{2}-\mathrm{Sb}$ produces a remarkable stabilizing effect, so that the service life is increased by two orders of magnitude (Table 3). Similar service lifes in alkaline medium were observed by Adams et al., ${ }^{31}$ by introducing $\mathrm{Pt}$ in $\mathrm{SnO}_{2}-\mathrm{Sb}_{2} \mathrm{O}_{5}$ electrodes, but using milder anodic polarization conditions $\left(0.16 \mathrm{~A} \mathrm{~cm}^{-2}\right.$ and $\left.0.5 \mathrm{M} \mathrm{NaOH}\right)$ and larger Pt contents $\left(\mathrm{PtO}_{\mathrm{x}}(10 \mathrm{wt}\right.$ \% $\left.)\right)$. Nevertheless, the service life of these electrodes in alkaline 
medium is still lower than that in acid conditions, in which Pt was found to cause proportional stabilizing effects.

The substitution of $\mathrm{Sb}$ by $\mathrm{Ru}$ in the nominal composition causes an increase in the service life of $\mathrm{SnO}_{2}-\mathrm{Sb} / \mathrm{Ti}$ and $\mathrm{SnO}_{2}-\mathrm{Sb}-\mathrm{Pt} / \mathrm{Ti}$ electrodes in alkaline conditions. In the presence of $\mathrm{Pt}$, the introduction of $\mathrm{Ru}$ increases the service life by up to one order of magnitude for the 9.75 at. \% electrode. To the knowledge of the authors, the only study on the stability of binary $(\mathrm{Sn}-\mathrm{Ru}) \mathrm{O}_{2}$ oxides in alkaline conditions was carried out by Lyons and Burke, ${ }^{57}$ who obtained a maximum service life of $240 \mathrm{~h}$ in stronger conditions $\left(6 \mathrm{M} \mathrm{NaOH} ; 0,75 \mathrm{~A} \mathrm{~cm}^{-2}\right.$ and $\left.80^{\circ} \mathrm{C}\right)$ for a thicker electrode $\left(4 \mathrm{mg} \mathrm{cm}^{-2}\right)$ with $40 \% \mathrm{RuO}_{2}$. In terms of efficiency, the service life (SLE) of these electrodes (45 $\mathrm{Ah} \mathrm{mg}^{-1}$ ) was considerably lower than those found in this work for Pt- and Rudoped $\mathrm{SnO}_{2}$ anodes (63-106 $\mathrm{A} \mathrm{h} \mathrm{mg}^{-1}$ ) (Table 3), by using even about 4-12 times higher $\mathrm{Ru}$ contents in the former case. The highest stabilities obtained by combining low amounts of Pt (3 $\%)$ and $\mathrm{Ru}(3.25-6.50$ at. \%) highlights the outstanding synergistic effect of $\mathrm{Pt}$ and $\mathrm{Ru}$ in these quaternary $\mathrm{SnO}_{2}-\mathrm{Sb}(13-\mathrm{x})-\mathrm{Pt}-\mathrm{Ru}(\mathrm{x}) / \mathrm{Ti}$ mixed oxides. Several strategies have been used in order to improve the service life of these types of electrodes. Recently, the introduction of carbon nanotubes $(\mathrm{CNT})$ in the $\mathrm{Ti} / \mathrm{SnO}_{2}-\mathrm{Sb}-\mathrm{CNT}$ composition increases the service life 4.8 times compared to the $\mathrm{Ti} / \mathrm{SnO}_{2}-\mathrm{Sb}$ electrode, showing a superior electrochemical oxidation and degradation abilities for organic pollutants ${ }^{30}$.

\subsubsection{Characterization of deactivated electrodes.}

Although a little more cracked and deteriorated, the surface texture of the deactivated $\mathrm{SnO}_{2}-\mathrm{Sb}$ electrode (Fig. 1b) is rather similar to that of the fresh ones (Fig. 1a), whereas the deactivated $\mathrm{SnO}_{2}$-Sb-Pt electrode additionally exhibits the detachment of some regions of the oxide coating 
throughout the whole surface (Fig. 1f) exposing the Ti substrate to the electrolyte (Fig. 1g). In $\mathrm{RuO}_{2} / \mathrm{Ti}$ electrodes, the anodic polarization process produces the detachment of almost the whole $\mathrm{RuO}_{2}$ layer and only some small fragments remain attached to the support surface after deactivation (Fig. 1d). On the other hand, and independently of the Ru content, deactivated $\mathrm{SnO}_{2}-\mathrm{Sb}(13-\mathrm{x})-\mathrm{Pt}-\mathrm{Ru}(\mathrm{x}) / \mathrm{Ti}$ and $\mathrm{SnO}_{2}-\mathrm{Ru} / \mathrm{Ti}$ electrodes showed a more pronounced detachment of the oxide layer than in the case of $\mathrm{SnO}_{2}-\mathrm{Sb}-\mathrm{Pt} / \mathrm{Ti}$ electrode, with small coating fragments but less marked than that of $\mathrm{RuO}_{2} / \mathrm{Ti}$. The $\mathrm{Sn} / \mathrm{M}$ ratio is practically maintained in the deactivated electrodes; however, the $\mathrm{Sb} / \mathrm{M}$ and $\mathrm{Ru} / \mathrm{M}$ ratios decrease (Table 1), and the $\mathrm{Pt} / \mathrm{M}$ increases.

The partial detachment of the outer or a localized-region of the $\mathrm{SnO}_{2}$-based oxide layers was evidenced by i) the presence of $\mathrm{Sn}, \mathrm{Sb}$ and $\mathrm{Pt}$ in the used alkaline electrolytes (even in the case of $\mathrm{SnO}_{2}-\mathrm{Sb}$ ), as determined by ICP analysis; ii) the appearance or increase of Ti signal in XPS or EDX and XRD results (Fig. S2). In spite of the damage of the outer surface layers, XPS revealed that the anodic polarization does not modify the binding energies of $\operatorname{Sn}(3 \mathrm{~d}), \mathrm{Sb}(3 \mathrm{~d})$ and $\mathrm{O}(1 \mathrm{~s})$ core levels (Fig. 4) of the deactivated electrodes, although metallic Pt completely transforms into oxidized Pt (II) and Pt (IV) species (Fig. S1a). ${ }^{43}$ Moreover, XRD patterns of deactivated electrodes still keep the characteristic rutile-like structure.

The detailed analysis of core level photoelectron spectra of the different deactivated $\mathrm{SnO}_{2}$-based electrodes show a decrease in the $\mathrm{I}_{\mathrm{OH}} / \mathrm{I}_{\mathrm{OM}}$ ratios (Table 1), indicating a higher relative increase in the amount of oxygen atoms bonded to metal (OM). Moreover, the effect of Ru content in the binding energies of $\mathrm{Sn} 3 \mathrm{~d}_{3 / 2}$ and $3 \mathrm{~d}_{5 / 2}$ states of the different Ru-doped $\mathrm{SnO}_{2}$ electrodes, disappears after deactivation (Fig. 4b). Also their voltammograms show a dramatic loss of the voltammetric charge and do not exhibit the characteristic redox peaks of Ru species within the 
entire potential range (Fig. 8c-h). The onset of the OER is also shifted to more positive potentials.

The similarity between the surface $\mathrm{Sn} / \mathrm{M}$ atomic ratio of fresh and deactivated $\mathrm{SnO}_{2}-\mathrm{Sb}$ and $\mathrm{SnO}_{2}$-Sb-Pt electrodes, determined by XPS (Table 1), together with the general decrease in the corrected $\mathrm{I}_{\mathrm{OH}} / \mathrm{I}_{\mathrm{OM}}$ ratios, seem to rule out the formation of a passivating surface layer of tin hydroxides $\left(\mathrm{Sn}(\mathrm{OH})_{4}\right)$ and/or hydrates. ${ }^{43}$ These facts reveal that the deactivation mechanism of these electrodes in alkaline conditions is different to that proposed for acid medium. ${ }^{20,26,43}$ On the other hand, the similar voltammetric profile of fresh and deactivated electrodes (Fig. 8) indicates that the $\mathrm{SnO}_{2}-\mathrm{Sb} / \mathrm{Ti}$ and $\mathrm{SnO}_{2}-\mathrm{Sb}-\mathrm{Pt} / \mathrm{Ti}$ deactivated ones preserve the ability to transfer charge across the surface. The OER currents are considerably tilted, especially in the case of $\mathrm{SnO}_{2}-\mathrm{Sb} / \mathrm{Ti}$ electrodes. This fact may be due to the growth of a $\mathrm{TiO}_{2}$ interlayer. ${ }^{58}$ In the case of $\mathrm{SnO}_{2}-\mathrm{Sb}$ $\mathrm{Pt} / \mathrm{Ti}$ the conversion of metallic $\mathrm{Pt}$ to $\mathrm{Pt}(\mathrm{IV})$ and $\mathrm{Pt}(\mathrm{II})$ species can originate a reduction in the number of oxygen vacancies $^{42}$ and a decrease of its electrocatalytic activity for OER. Consequently, the deactivation of $\mathrm{SnO}_{2}-\mathrm{Sb}$ and $\mathrm{SnO}_{2}-\mathrm{Sb}-\mathrm{Pt}$ electrodes in $\mathrm{NaOH}$ is proposed to occur by a non-selective dissolution of metallic species in alkaline conditions, accompanied by some degree of coating detachment, that allows the $\mathrm{NaOH}$ electrolyte to contact and passivate the $\mathrm{MO}_{\mathrm{x}} / \mathrm{Ti}$ interphase. ${ }^{59}$

The detachment of the whole $\mathrm{RuO}_{2}$ coating in $\mathrm{RuO}_{2} / \mathrm{Ti}$ electrodes was confirmed by the remarkably high $\mathrm{Ti} / \mathrm{M}$ ratio and the increase of both the Ti(2p) core-level peak (associated with $\left.\mathrm{TiO}_{2}\right)^{60}$ (Fig. S1b) and the relative intensity of Ti diffraction peaks (Fig. S2), as well as the decrease in the $\mathrm{Ru}(3 \mathrm{~d})$ photoelectron peak (Fig. 4d), the complete disappearance of $\mathrm{RuO}_{2}$ diffraction peaks (Fig. S2b) and the absence of Ru redox peaks and extremely low currents in its $\mathrm{CV}$ profile (Fig. 8h). This may be related to the electrochemical dissolution of $\mathrm{RuO}_{2}$ in alkaline 
medium at high potentials, ${ }^{57}$ which has been associated with the electrochemical generation of soluble $\mathrm{RuO}_{4}{ }^{2-}$ species during $\mathrm{O}_{2}$ production:

$(-\mathrm{O}-)_{2} \mathrm{RuO}_{2}(\mathrm{OH})_{2}+2 \mathrm{H}_{2} \mathrm{O} \leftrightarrow 2(-\mathrm{OH})+\mathrm{RuO}_{2}(\mathrm{OH})_{4}$

$\mathrm{RuO}_{2}(\mathrm{OH})_{4}+4 \mathrm{OH}^{-} \leftrightarrow \mathrm{RuO}_{4}^{2-}+4 \mathrm{H}_{2} \mathrm{O}+2 \mathrm{e}^{-}+\mathrm{O}_{2}$

From the detailed characterization of fresh and deactivated electrodes it is proposed that the anodic deactivation of $\mathrm{SnO}_{2}-\mathrm{Sb}(13-\mathrm{x})-\mathrm{Pt}-\mathrm{Ru}(\mathrm{x}) / \mathrm{Ti}$ electrodes in $\mathrm{NaOH}$ electrolyte, occurs by a mixed mechanism. Thus, dissolution of metallic species, promoted in alkaline conditions and high potentials, the loss of coating and the passivation of $\mathrm{Ti}$ substrate, by formation of an insulating $\mathrm{TiO}_{2}$ interlayer, act together. Considering this mechanism and the service life of the different electrodes in $\mathrm{NaOH}$ (Table 3), the stabilizing effect of Pt may be attributed to its surface compacting effect, what may hinder the penetration of the electrolyte through the coating, and/or to prevent the generation of surface insulating $\mathrm{Sn}(\mathrm{OH})_{\mathrm{x}} \operatorname{species}^{28}$ and/or $\mathrm{Sb}^{3+}$ species, which could be important active sites for oxygen and water adsorption. ${ }^{61}$ On the other hand, regarding the similarities in microstructure observed by XRD and TEM, the enhanced stability caused by the progressive substitution of $\mathrm{Sb}$ by $\mathrm{Ru}$ up to a 9.75 at. \% $\mathrm{Ru}$, at which $\mathrm{Sn}$ and $\mathrm{Ru}$ form a solid solution, together with the decreased stability observed for higher $\mathrm{Ru}$ contents ( $x>9.75$ at. \%), for which a $\mathrm{RuO}_{2}$ phase segregation is observed, allow us to suggest that the formation of a homogeneous $\left(\mathrm{Ru}_{\delta} \mathrm{Sn}_{1-\delta}\right) \mathrm{O}_{2}$ single-phase must be the key factor explaining the high stability of $\mathrm{SnO}_{2}-\mathrm{Sb}(13-\mathrm{x})-\mathrm{Pt}-\mathrm{Ru}(\mathrm{x}) / \mathrm{Ti}$ electrodes. In addition, the high stability of the highest oxidation states of $\mathrm{Ru}$ and $\mathrm{Pt}$ in alkaline conditions, at potentials where the OER occurs, may also contribute. In this sense, the $\mathrm{Ru}$-doped $\mathrm{SnO}_{2}$ electrodes may experience deactivation after the observed selective dissolution of $\mathrm{Ru}$ from the $\left(\mathrm{Ru}_{\delta} \mathrm{Sn}_{1-\delta}\right) \mathrm{O}_{2}$ 
phase, which may bring about the coating detachment and the access of electrolyte to the $\mathrm{Ti}$ support. On the other hand, the segregation of $\mathrm{RuO}_{2}$ phase may promote the generation of crystalline and structural defects, which could facilitate the dissolution of inner metal species and the penetration of $\mathrm{NaOH}$ electrolyte.

\section{Conclusions}

The introduction of $\mathrm{Pt}\left(3\right.$ at.\%) and the nominal substitution of $\mathrm{Sb}\left(13\right.$ at.\%) by $\mathrm{Ru}$ in $\mathrm{SnO}_{2}-\mathrm{Sb}$ and $\mathrm{SnO}_{2}-\mathrm{Sb}-\mathrm{Pt}$ electrodes induce different textural, structural and chemical changes that strongly affect the electrocatalytic activity for the OER and electrochemical stability in alkaline conditions. Although both $\mathrm{Pt}$ and $\mathrm{Ru}$ are mainly incorporated in the bulk of the $\mathrm{SnO}_{2}-\mathrm{Sb}(13-\mathrm{x})$ $\mathrm{Pt}-\mathrm{Ru}(\mathrm{x})$ electrodes, they introduce their characteristic redox processes and shift the onset of the OER towards lower potentials. However, while Pt does not alter neither the Sn and Sb contents nor the rutile-like crystalline structure, XPS and XRD analysis have shown that, Ru content lower than 9.75 at. \%, $\mathrm{Ru}(\mathrm{IV})$ atoms, instead of replacing $\mathrm{Sb}$ in the mixed oxides (as it could be expected from the change on nominal compositions), occupy positions of $\operatorname{Sn}(\mathrm{IV})$ ions in the cationic sub-lattice of the rutile-like $\mathrm{SnO}_{2}$ structure to form a solid solution. In addition, surface segregation of $\mathrm{Ru}$ is observed as $\mathrm{RuO}_{2}$ phase at $\mathrm{Ru}$ contents larger than 9.75 at.\%.

The deactivation of the different electrodes has been found to occur by passivation of the Ti substrate and/or detachment of the oxide coating promoted by alkaline dissolution of metal species at high potentials. Considering this mechanism, Pt causes a compacting effect on the cracked-mud morphology of the $\mathrm{SnO}_{2}-\mathrm{Sb}$ coating that, together with its stability under OER conditions, results an increase in the "accelerated" service life of this electrode by two orders of magnitude in alkaline medium. Moreover, the introduction of low amounts of Ru (3.25-9.75 at. 
\%) into the $\mathrm{SnO}_{2}$ rutile-like structure leads to a three-fold increase in the service life of $\mathrm{SnO}_{2}-\mathrm{Sb}$ $\mathrm{Pt} / \mathrm{Ti}$ electrodes. However, a further gain in stability with higher $\mathrm{Ru}$ contents is not observed probably because of the mixed metal oxide saturation, which leads to $\mathrm{Ru}$ segregation as a $\mathrm{RuO}_{2}$ phase.

Consequently, the obtained results show that the combination of low amounts of $\mathrm{Pt}$ and $\mathrm{Ru}$ (below the saturation of $\left(\mathrm{Ru}_{\delta} \mathrm{Sn}_{1-\delta}\right) \mathrm{O}_{2}$ solid solutions) greatly enhances the stability of $\mathrm{SnO}_{2}-\mathrm{Sb}$ electrodes in alkaline medium. Although the stability of these electrodes does not reach that observed for pure $\mathrm{RuO}_{2}$, they constitute cheaper alternatives with a higher OER overpotential as attractive properties for different applications in alkaline medium, such as electro-oxidation of compounds in electrosynthesis and electrochemical degradation of pollutants.

\section{ASSOCIATED CONTENT}

\section{Supporting Information}

Additional XPS, XRD and Tafel plots information. This material is available free of charge via the Internet at http://pubs.acs.org.

\section{AUTHOR INFORMATION}

\section{Corresponding Author}

*Email: morallon@ua.es.

\section{ACKNOWLEDGEMENTS}

The authors thanks to the MINECO, FEDER and Generalitat Valenciana for the financial support (MAT2013-42007-P, PROMETEO2013/028 projects).

\section{REFERENCES}


(1) Trasatti, S. Transition Metal Oxides: Versatile Materials for Electrocatalysis. In The Electrochemistry of Novel Materials; Lipkowski, J.; Ross, P. N., Eds.; VCH Publisher Inc.; Weinheim, 1994, pp 207-295.

(2) Hayfield, P. C. S. Development of the Noble Metal/Oxide Coated Titanium Electrode Part III: Coated Titanium Anodes in Widely Ranging Oxygen Evolving Situations. Platinum Met. Rev. 1998, 42, 116-122.

(3) Park, S.; Shao, Y.; Liu, J.; Wang, Y. Oxygen Electrocatalysts for Water Electrolyzers and Reversible Fuel Cells: Status and Perspective. Energy Environ. Sci. 2012, 5, 9331-9344.

(4) McCrory, C. C. L.; Jung, S.; Peters, J. C.; Jaramillo, T. F. Benchmarking Heterogeneous Electrocatalysts for the Oxygen Evolution Reaction. J. Am. Chem. Soc. 2013, 135, 16977-16987.

(5) Martínez-Huitle, C. A.; Ferro, S. Electrochemical Oxidation of Organic Pollutants for the Wastewater Treatment: Direct and Indirect Processes. Chem. Soc. Rev. 2006, 35, 1324-1340.

(6) Comninellis, Ch.; Pulgarin, C. Anodic Oxidation of Phenol for Waste-Water Treatment. J. Appl. Electrochem. 1991, 21, 703-708.

(7) Chen, G.; Hung, Y. T. Electrochemical Wastewater Treatment Processes. In Advanced Physicochemical Treatment Technologies; Wang, L. K.; Hung, Y. T.; Shammas, N. K., Eds.; Handbook of Environmental Engineering Series 5, Springer-Verlag; New York, LLC, 2007; pp $57-106$.

(8) Berenguer, R.; Marco-Lozar, J. P.; Quijada, C.; Cazorla-Amorós, D.; Morallón, E. Electrochemical Regeneration and Porosity Recovery of Phenol-saturated Granular Activated Carbon in an Alkaline Medium. Carbon 2010, 48, 2734-2745. 
(9) Berenguer, R.; Marco-Lozar, J. P.; Quijada, C.; Cazorla-Amorós, D.; Morallón, E. Comparison among Chemical, Thermal, and Electrochemical Regeneration of Phenol-Saturated Activated Carbon. Energy Fuels 2010, 24, 3366-3372.

(10) Lin, H.; Niu, J.; Ding, S.; Zhang, L. Electrochemical Degradation of Perfluorooctanoic Acid (PFOA) by $\mathrm{Ti} / \mathrm{SnO}_{2}-\mathrm{Sb}, \mathrm{Ti} / \mathrm{SnO}_{2}-\mathrm{Sb} / \mathrm{PbO}_{2}$ and $\mathrm{Ti} / \mathrm{SnO}{ }_{2}-\mathrm{Sb} / \mathrm{MnO}_{2}$ Anodes. Water Res. 2012, 46, 2281-2289.

(11) Lin, H.; Niu, J.; Xu, J.; Huang, H.; Li, D.; Yue, Z.; Feng, C. Highly Efficient and Mild Electrochemical Mineralization of Long-Chain Perfluorocarboxylic Acids (C9-C10) by $\mathrm{Ti} / \mathrm{SnO}_{2}-\mathrm{Sb}-\mathrm{Ce}, \mathrm{Ti} / \mathrm{SnO}_{2}-\mathrm{Sb} / \mathrm{Ce}-\mathrm{PbO}_{2}$, and $\mathrm{Ti} / \mathrm{BDD}$ Electrodes. Environ. Sci. Technol. 2013, 47, 13039-13046.

(12) Niu, J.; Bao, Y.; Li, Y.; Chai, Z. Electrochemical Mineralization of Pentachlorophenol (PCP) by Ti/SnO $2-\mathrm{Sb}$ Electrodes. Chemosphere 2013, 92, 1571-1577.

(13) Simon, P.; Gogotsi, Y. Materials for Electrochemical Capacitors. Nat. Mater. 2008, 7, $845-854$.

(14) Wang, G.; Zhang, L.; Zhang. J. A Review of Electrode Materials for Electrochemical Supercapacitors. Chem. Soc. Rev. 2012, 41, 797-828.

(15) Sieben, J. M.; Morallón, E.; Cazorla-Amorós, D. Flexible Ruthenium Oxide-Activated Carbon Cloth Composites Prepared by Simple Electrodeposition Methods. Energy 2013, 58, 519-526.

(16) Tarascon, J. M.; Armand, M. Issues and Challenges Facing Rechargeable Lithium Batteries. Nature 2001, 414, 359-367. 
(17) Trasatti, S. Electrocatalysis: Understanding the Success of DSA®. Electrochim. Acta 2000, 45, 2377-2385.

(18) Vercesi, G. P.; Rolewicz, J.; Comninellis, Ch.; Hinden, J. Characterization of DSA-Type Oxygen Evolving Electrodes. Choice of Base Metal. Thermochim. Acta 1991,176, 31-47.

(19) Comninellis, Ch.; Vercesi, G. P. Characterization of DSA-Type Oxygen Evolving Electrodes. Choice of a Coating. J. Appl. Electrochem. 1991, 21, 335-345.

(20) Stucki, S.; Kotz, R.; Carcer, B.; Suter, W. Electrochemical Waste-Water Treatment using High Overvoltage Anodes. 2. Anode Performance and Applications. J. Appl. Electrochem. 1991, $21,99-104$.

(21) Correa-Lozano, B.; Comninellis, Ch.; De Battisti, A. Service Life of Ti/ $\mathrm{SnO}_{2}-\mathrm{Sb}_{2} \mathrm{O}_{5}$ Anodes. J. Appl. Electrochem. 1997, 27, 970-974.

(22) Rodgers, J.D.; Jedral, W. J.; Bunce, N.J. Electrochemical Oxidation of Chlorinated Phenols. Environ. Sci. Technol. 1999, 33, 1453-1457.

(23) Cañizares, P.; Martínez, F.; Díaz, M.; García-Gómez, J.; Rodrigo, M. A. Electrochemical Oxidation of Aqueous Phenol Wastes Using Active and Nonactive Electrodes. J. Electrochem. Soc. 2002, 149, D118-D124.

(24) Montilla, F.; Michaud, P. A.; Morallón, E.; Vázquez, J. L.; Comninellis, Ch.; Electrochemical Oxidation of Benzoic Acid at Boron-Doped Diamond Electrodes. Electrochim. Acta 2002, 47, 3509-3513.

(25) Treimer, S. E.; Feng, J.; Scholten, M. D.; Johnson, D. C.; Davenport, A. J. Comparison of Voltammetric Responses of Toluene and Xylenes at Iron(III)-Doped, Bismuth(V)-Doped, and 
Undoped Beta-Lead Dioxide Film Electrodes in 0.50 $\mathrm{M} \mathrm{H}_{2} \mathrm{SO}_{4}$. J. Electrochem. Soc. 2001, 148, E459-E463.

(26) Vicent, F.; Morallon, E.; Quijada, C.; Vazquez, J. L.; Aldaz, A.; Cases, F. Characterization and Stability of Doped $\mathrm{SnO}_{2}$ Anodes. J. Appl. Electrochem. 1998, 28, 607-612.

(27) Ding, H. Y.; Feng, Y. J.; Lu, J. W. Study on the Service Life and Deactivation Mechanism of $\mathrm{Ti} / \mathrm{SnO}_{2}-\mathrm{Sb}$ Electrode by Physical and Electrochemical Methods. Russ. J. Electrochem. 2010, $46,72-76$.

(28) Montilla, F.; Morallón, E.; De Battisti, A.; Vázquez, J. L. Preparation and Characterization of Antimony-Doped Tin Dioxide Electrodes. Part 1. Electrochemical Characterization. J. Phys. Chem. B 2004, 108, 5036-5043.

(29) Forti, J. C.; Olivi, P.; de Andrade, A. R. Characterisation of DSA®-Type Coatings with Nominal Composition Ti/ $\mathrm{Ru}_{0.3} \mathrm{Ti}_{(0.7-x)} \mathrm{Sn}_{\mathrm{x}} \mathrm{O}_{2}$ Prepared Via a Polymeric Precursor. Electrochim. Acta 2001, 47, 913-920.

(30) Zhang, L.; Xu, L.; He, J.; Zhang, J. Preparation of Ti/SnO ${ }_{2}-\mathrm{Sb}$ Electrodes Modified by Carbon Nanotube for Anodic Oxidation of Dye Wastewater and Combination with Nanofiltration. Electrochim. Acta 2014, 117, 192-201.

(31) Adams, B.; Tian, M.; Chen, A. Design and Electrochemical Study of $\mathrm{SnO}_{2}$-based Mixed Oxide Electrodes. Electrochim. Acta 2009, 54, 1491-1498.

(32) Montilla, F.; Morallón, E.; Vázquez, J. L. Evaluation of the Electrocatalytic Activity of Antimony-Doped Tin Dioxide Anodes Toward the Oxidation of Phenol in Aqueous Solutions. $J$. Electrochem. Soc. 2005, 152, B421-B427. 
(33) Berenguer, R.; Quijada, C.; Morallón, E. Electrochemical Characterization of $\mathrm{SnO}_{2}$ Electrodes Doped with Ru and Pt. Electrochim. Acta 2009, 54, 5230-5238.

(34) Iwakura, C.; Sakamoto, K. Effect of Active Layer Composition on the Service Life of $\left(\mathrm{SnO}_{2}\right.$ and $\left.\mathrm{RuO}_{2}\right)$-Coated Ti Electrodes in Sulfuric-Acid Solution. J. Electrochem. Soc. 1985, $132,2420-2423$.

(35) Fachinotti, E.; Guerrini, E.; Tavares, A.C.; Trasatti, S. Electrocatalysis of $\mathrm{H}_{2}$ Evolution by Thermally Prepared Ruthenium Oxide: Effect of Precursors: Nitrate vs. Chloride. $J$. Electroanal. Chem. 2007, 600, 103-112.

(36) De Pauli, C. P.; Trasatti, S. Electrochemical Surface Characterization of $\mathrm{IrO}_{2}+\mathrm{SnO}_{2}$ Mixed-Oxide Electrocatalysts. J. Electroanal. Chem. 1995, 396, 161-168.

(37) Matko, I.; Gaidi, M.; Chenevier, B.; Charai, A.; Saikaly, W.; Labeau, M. Pt Doping of $\mathrm{SnO}_{2}$ Thin Films: A Transmission Electron Microscopy Analysis of the Porosity Evolution. $J$. Electrochem. Soc. 2002, 149, H153-H158.

(38) Ito, M.; Murakami, Y.; Kaji, H.; Yohikozawa, K.; Takasu, Y. Surface Characterization of $\mathrm{RuO}_{2}-\mathrm{SnO}_{2}$ Coated Titanium Electrodes. J. Electrochem. Soc. 1996, 143, 32-36.

(39) Nanni, L.; Polizzi, S.; Benedetti, A.; De Battisti, A. Morphology, Microstructure, and Electrocatalylic Properties of $\mathrm{RuO}_{2}-\mathrm{SnO}_{2}$ Thin Films. J. Electrochem. Soc. 1999, 146, 220-225.

(40) Wang, X.; Deng, F.; Tang, Z.; Wu, B.; Tang, D.; Lin, W. The Nature of Phase Separation in a Ru-Sn-O Ternary Oxide Electrocatalyst. Phys. Chem. Chem. Phys. 2013, 15, 3977-3984.

(41) Liu, W.; Cao, X.; Zhu, Y.; Cao, L. The Effect of Dopants on the Electronic Structure of $\mathrm{SnO}_{2}$ Thin Film. Sens. Actuators, B 2000, 66, 219-221. 
(42) Batzill, M.; Diebold, U. The Surface and Materials Science of Tin Oxide. Prog. Surf. Sci. 2005, 79, 47-154.

(43) Montilla, F.; Morallón, E.; De Battisti, A.; Barison, S.; Daolio, S.; Vázquez, J. L. Preparation and Characterization of Antimony-Doped Tin Dioxide Electrodes. 3. XPS and SIMS Characterization. J. Phys. Chem. B 2004, 108, 15976-15981.

(44) Montilla, F.; Morallón, E.; De Battisti, A.; Benedetti, A.; Yamashita, H.; Vázquez, J. L. Preparation and Characterization of Antimony-Doped Tin Dioxide Electrodes. Part 2. XRD and EXAFS Characterization. J. Phys. Chem. B 2004, 108, 5044-5050.

(45) Terrier, C.; Chatelon, J. P.; Roger, J. A.; Berjoan, R.; Dubois, C. Analysis of Antimony Doping in Tin Oxide Thin Films Obtained by the Sol-Gel Method. J. Sol-Gel Sci. Technol. 1997, $10,75-81$.

(46) Slater, B.; Catlow, C. R.; Gay, D. H.; Williams, D. E.; Dusastre, V. Study of Surface Segregation of Antimony on $\mathrm{SnO}_{2}$ Surfaces by Computer Simulation Techniques. J. Phys. Chem. $B$ 1999, 103, 10644-10650.

(47) Rochefort, D.; Daboa, P.; Guay, D.; Sherwood, P. M. A. XPS Investigations of Thermally Prepared $\mathrm{RuO}_{2}$ Electrodes in Reductive Conditions. Electrochim. Acta 2003, 48, 4245-4252.

(48) Gaudet, J.; Tavares, A. C.; Trasatti, S.; Guay, D. Physicochemical Characterization of Mixed $\mathrm{RuO}_{2}-\mathrm{SnO}_{2}$ Solid Solutions. Chem. Mater. 2005, 17, 1570-1579.

(49) Berenguer, R.; Valdés-Solís, T.; Fuertes, A. B.; Quijada, C.; Morallón, E. Cyanide and Phenol Oxidation on Nanostructured $\mathrm{Co}_{3} \mathrm{O}_{4}$ Electrodes Prepared by Different Methods. $J$. Electrochem. Soc. 2008, 155, K110-K115. 
(50) Kim, K. W.; Lee, E. H.; Kim, J. S.; Shin, K. H.; Kim, K. H. Study on the Electroactivity and Non-Stochiometry of a Ru-based Mixed Oxide Electrode. Electrochim. Acta 2001, 46, 915921.

(51) Ardizzone, S.; Fregonara, G.; Trasatti, S. Inner and Outer Active Surface of $\mathrm{RuO}_{2}$ Electrodes. Electrochim. Acta 1990, 35, 263-267.

(52) Wu, N. L.; Hwang, J. Y.; Liu, P. Y.; Han, C. Y.; Kuo, S. L.; Liao, K. H.; Lee, M. H.; Wang, S. Y. Synthesis and Characterization of Sb-Doped $\mathrm{SnO}_{2}$ Xerogel Electrochemical Capacitor. J. Electrochem. Soc. 2001, 148, A550-A553.

(53) Sugimoto, W.; Kizaki, T.; Yokoshima, K.; Murakami, Y.; Takasu, Y. Evaluation of the Pseudocapacitance in $\mathrm{RuO}_{2}$ with a $\mathrm{RuO}_{2} / \mathrm{GC}$ Thin Film Electrode. Electrochim. Acta 2004, 49, $313-320$.

(54) Bard, A. J.; Faulkner, L. R. Electrochemical Methods 1980, John Wiley\& Sons: New York.

(55) Consonni, V.; Trasatti, S.; Pollak, F.; O’Grady, W. E. Mechanism of Chlorine Evolution on Oxide Anodes. Study of pH Effects. J. Electroanal. Chem. 1987, 228, 393-406.

(56) Mattos-Costa, F. I.; de Lima-Neto, P.; Machado, S. A. S.; Avaca, L. A. Characterisation of Surfaces Modified by Sol-Gel Derived $\mathrm{Ru}_{\mathrm{x}} \mathrm{Ir}_{1-\mathrm{x}} \mathrm{O}_{2}$ Coatings for Oxygen Evolution in Acid Medium. Electrochim. Acta 1998, 44, 1515-1523.

(57) Lyons, M. E. G.; Burke, L. D. Mechanism of Oxygen Reactions at Porous Oxide Electrodes. 1. Oxygen Evolution at $\mathrm{RuO}_{2}$ and $\mathrm{Ru}_{\mathrm{x}} \mathrm{Sn}_{1-\mathrm{x}} \mathrm{O}_{2}$ Electrodes in Alkaline-Solution under Vigorous Electrolysis Conditions. J. Chem. Soc., Faraday Trans. 1 1987, 83, 299-321. 
(58) Boodts, J. F. C.; Trasatti, S. Effect of Composition on the Electrocatalytic Activity of the Ternary Oxide $\mathrm{Ru}_{0.3} \mathrm{Ti}_{0.7-\mathrm{x}} \mathrm{Sn}_{\mathrm{x}} \mathrm{O}_{2}$. 1. Oxygen Evolution from $\mathrm{HClO}_{4}$ Solution. J. Electrochem. Soc. 1990, 137, 3784-3789.

(59) Beck, F. Wear Mechanisms of Anodes. Electrochim. Acta 1989, 34, 811-822.

(60) Hopfengärtner, G.; Borgmann, D.; Rademacher, I.; Wedler, G.; Hums, E.; Spitznagel, G. W. XPS Studies of Oxidic Model Catalysts: Internal Standards and Oxidation Numbers. J. Electron Spectros. Relat. Phenom. 1993, 63, 91-116.

(61) Dusastre, V.; Williams, D. E. Sb(III) as a Surface Site for Water Adsorption on $\mathrm{Sn}(\mathrm{Sb}) \mathrm{O}_{2}$, and its Effect on Catalytic Activity and Sensor Behavior. J. Phys. Chem. B 1998, 102, 67326737. 


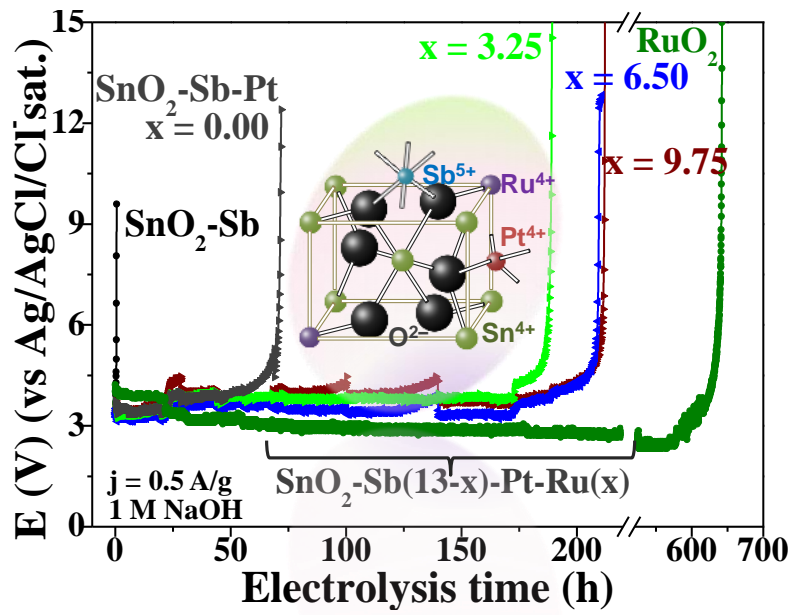

